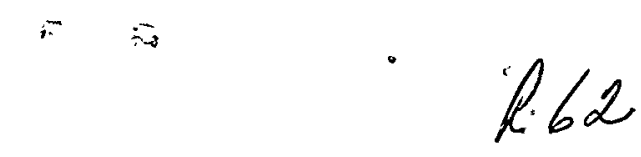

FISCAL YEAR 1998 YEAR-END REPORT

for the November 1997 to October 1998 Period

\title{
INVESTIGATION OF WASTE GLASS POURING PROCESS OVER A KNIFE EDGE
}

Principal Investigator:

M.A. Ebadian, Ph.D.

Florida International University Collaborators:

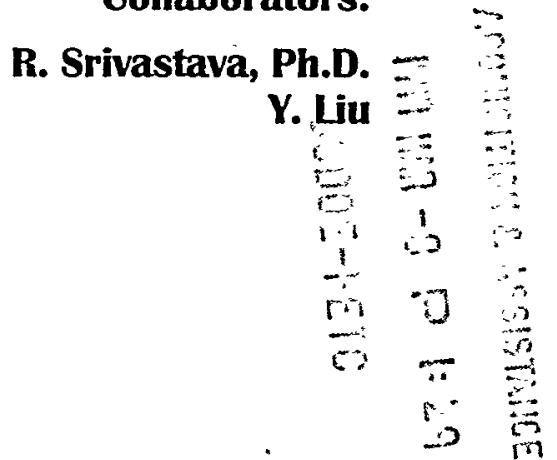

Prepared for:

U.S. Department of Energy Office of Environmental Management Office of Science and Technology

Hemispheric Center for Environmental Technology (HCET) Florida International University, Center for Engineering \& Applied Sciences 10555 West Flagler Street, EAS-2100, Miami, Florida 33174 305-348-4238 • FAX: (305) 348-1852 - World Wide Web Site: http://www.hcet.fiu.edu

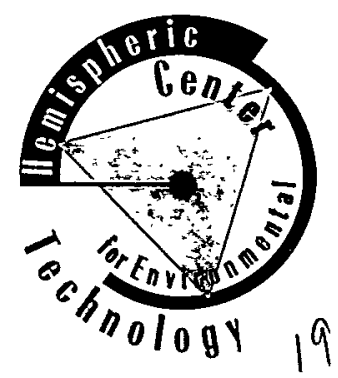




\section{DISCLAIMER}

This report was prepared as an account of work sponsored by an agency of the United States government. Neither the United States government nor any agency thereof, nor any of their employees, nor any of its contractors, subcontractors, nor their employees makes any warranty, express or implied, or assumes any legal liability or responsibility for the accuracy, completeness, or usefulness of any information, apparatus, product, or process disclosed, or represents that its use would not infringe upon privately owned rights. Reference herein to any specific commercial product, process, or service by trade name, trademark, manufacturer, or otherwise does not necessarily constitute or imply its endorsement, recommendation, or favoring by the United States government or any other agency thereof. The views and opinions of authors expressed herein do not necessarily state or reflect those of the United States government or any agency thereof. 


\section{DISCLAIMER}

Portions of this document may be illegible in electronic image products. Images are produced from the best available original document. 


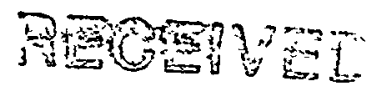 \\ JAN 05223 \\ Principal Investigator \\ 85 \\ M.A. Ebadian \\ Hemispheric Center for Environmental Technology \\ Florida International University \\ Miami, FL 33174
}

\title{
Florida International University \\ Collaborators
}

\author{
R. Srivastava \\ Y. Liu \\ Hemispheric Center for Environmental Technology \\ Florida International University \\ Miami, FL 33174
}

January 1999

Prepared for

U.S. Department of Energy

Office of Environmental Technology

Office of Science and Technology

Under Grant No.: DE-FG21-95EW55094 


\section{TABLE OF CONTENTS}

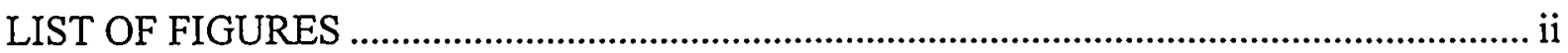

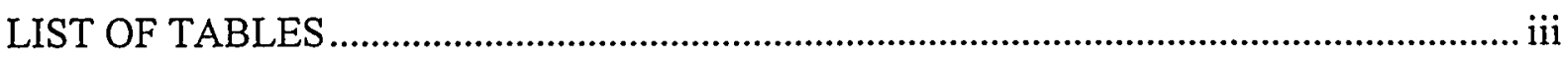

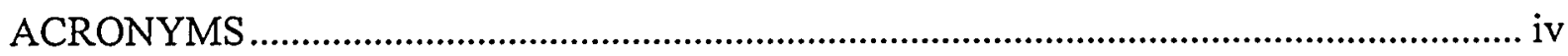

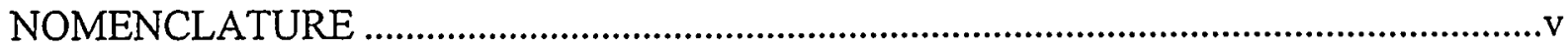

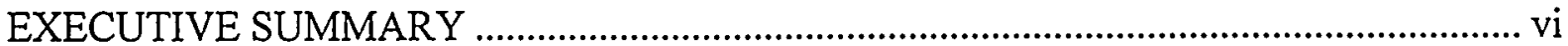

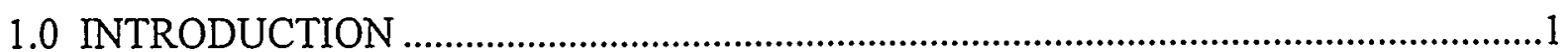

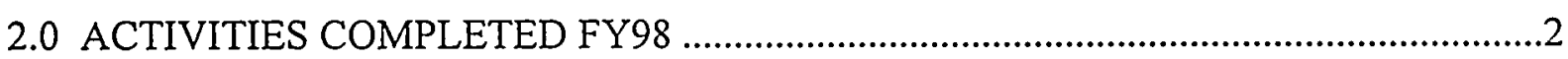

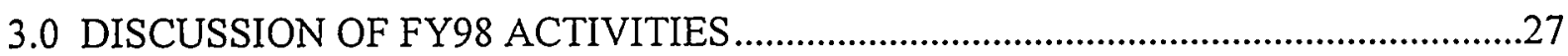

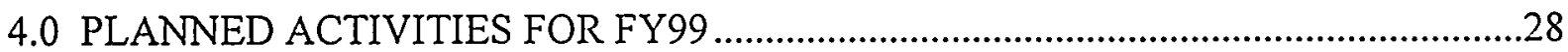

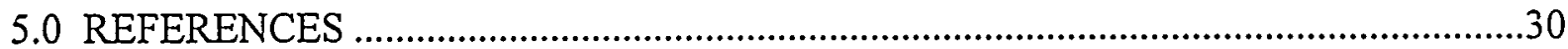

Appendix A. Furnace delivery photographs

Appendix B. Heating element breakage

Appendix C. Temperature profiles for glass flow experiments Performed on Thirteen Different Dates 


\section{LIST OF FIGURES}

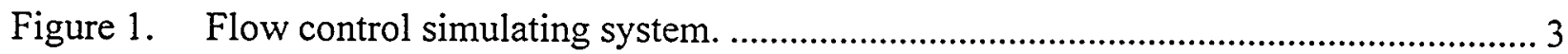

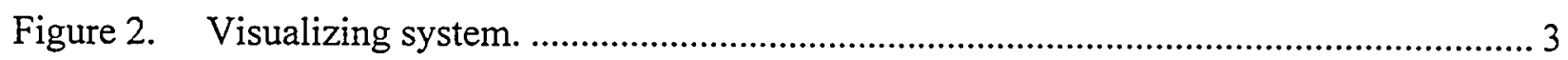

Figure 3. The relation of heating time and temperature ................................................... 4

Figure 4. Weight of glycerin pressed out of tank by nitrogen (nitrogen pressure: $20 \mathrm{psi}$ )........................................................................... 5

Figure 5. Weight of water pressed out of tank by nitrogen gas

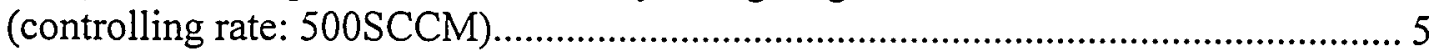

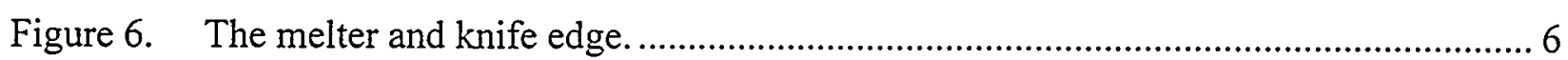

Figure 7. Glycerin flows through the knife edge............................................................. 7

Figure 8. Complete experimental system setup. ........................................................... 8

Figure 9. Schematic showing the glass film measurements to be recorded during the experiments. .................................................................. 9

Figure 10. Weight increment and melter temperature during glass

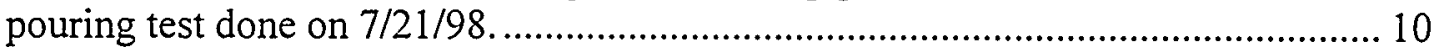

Figure 11. Increase in $W_{F}$, front glass film thickness with increase in glass flowrate. ............. 13

Figure 12. Increase in $W_{T}$, top glass film thickness with increase in glass flowrate................ 13

Figure 13. Increase in $\mathrm{Y}$, glass film thickness with increase in glass flowrate......................... 14

Figure 14. Variation of $\mathrm{W}_{\mathrm{F}}$, front glass film thickness with change of glass and pour spout temperature.

Figure 15. Variation of $\mathrm{W}_{\mathrm{T}}$, top glass film thickness with change of glass and pour spout temperature.

Figure 16. Variation of glass stream deflection and glass film thickness with change of glass and pour spout temperature.

Figure 17. Variation of $\mathrm{W}_{\mathrm{F}}$, front glass film thickness with change of pour spout temperature at fixed glass temperature of $1150^{\circ} \mathrm{C}$.

Figure 18. Variation of $W_{\mathrm{T}}$, top glass film thickness with change of pour spout temperature at fixed glass temperature of $1150^{\circ} \mathrm{C}$.

Figure 19. Variation of glass stream deflection and glass film thickness with change of pour spout temperature at fixed glass temperature of $1150^{\circ} \mathrm{C}$.

Figure 20. Variation of $W_{F}$, front glass film thickness with change in glass temperature.

Figure 21. Variation of $W_{T}$, top glass film thickness with change in glass temperature. 
Figure 22. Variation of glass stream deflection and glass film thickness with change in glass temperature.

Figure 23. Test condition showing negligible glass flow fluctuations with upstream pressure variations.

Figure 24. Schematic of melter.

Figure 25. Increase in melter pressure for a gas flow rate of $50 \mathrm{cc} / \mathrm{min}$ and an initial glass height of 8 ". It will take $5.76 \mathrm{~min}$. for the glass to rise to the top of the riser.

\section{LIST OF TABLES}

Table 1. Glass film thickness data for the baseline runs ......................................................... 11 


\section{ACRONYMS}

HCET Hemispheric Center for Environmental Technology

FIU Florida International University

DWPF Defense Waste Processing Facility

WSRC Westinghouse Savannah River Company

SRS Savannah River Site

SRTC Savannah River Technical Committee 


\section{NOMENCLATURE}

q inlet flowrate of gas in the melter head space, $\mathrm{cc} / \mathrm{min}$

$h_{0} \quad$ initial level of glass in the melter, in

$h_{1} \quad$ decrease in glass level in the melter, in

$\mathrm{h}_{2} \quad$ increase of glass level in the riser, in

W glass flowrate from the melter corresponding to $\mathrm{q}(\mathrm{cc} / \mathrm{min})$ of gas flowrate, $(\mathrm{lbs} / \mathrm{hr})$. 


\section{EXECUTIVE SUMMARY}

Vitrification is the process of capturing radioactive waste in glass. The Savannah River Site's (SRS) Defense Waste Processing Facility (DWPF) is one of the facilities using the vitrification technology to treat and immobilize radioactive waste since March 1996. However, the operation has been marked by extreme difficulty in maintaining a stable pouring process. There have been flow fluctuations accompanied by an unusual flow phenomenon, termed "wicking." In this situation, the falling glass stream wavers and departs from a normal vertical trajectory. The pour spout and associated hardware connecting it to the canister have been coated and often plugged with glass. The objective of the project is to investigate the pouring behavior of molten glass over a pour spout knife edge. Experiments are run using simulant glass containing the same chemical formulation as the radioactive sludge glass, but without radioactive contaminants. The purpose of these tests is to obtain actual glass data, which when combined with previous cold data from other fluids will provide an overall understanding of the physics of liquids flowing over a pour spout and knife edge. A specific objective is to verify computational fluid dynamic (CFD) models with a range of liquid data with particular emphasis on glass so as to provide confidence in use of these CFD models for designing a new improved pour spout for the DWPF melter. The work to be performed at Florida International University's Hemispheric Center for Environmental Technology (FIU-HCET) includes assembling the melting and pouring system that mimics the DWPF melter and determining the key parameters that may influence wicking. Information from the FIU-HCET melter tests will lead to better operating guidelines for the DWPF melter so as to avoid wicking.

FIU-HCET experimental system for glass melting and pouring consists of five subsystems: the melter and pour spout; the flow control and loading system; the temperature measurement and control system; the visualization system; and the data acquisition system. FIU-HCET glass pouring system is unique as there are four strategically placed quartz windows on the pour spout that provide top view, front view, and two side views for viewing the flow behavior of the molten glass over the knife edge. For the experiments, the furnace with solid glass in the melter is heated. As the temperature is increased from the room temperature $\left(\approx 30^{\circ} \mathrm{C}\right)$, viscosity of glass decreases and it becomes molten (glass transition temperature $=489^{\circ} \mathrm{C}$ ). When it reaches the desired temperature, typically in the $1050^{\circ} \mathrm{C}-1150^{\circ} \mathrm{C}$ range, nitrogen is introduced in the head space above the viscous glass in the melter. The gas forces the viscous glass to flow up through the vertical riser, traverse the horizontal section, and finally come down and out through the pour spout. Adjusting the flow rate of nitrogen controls the flow rate of the glass. The system can reach a maximum flow rate of $500 \mathrm{lb} / \mathrm{hr}$ of the molten glass.

A load cell monitors the glass flow rate and a computer connected to a data acquisition system records the data. As mentioned earlier, the system monitors four different views of glass flow over knife edge in the pouring section. The four views are recorded on videotape. The caliper measures the width of the glass film. Baseline experiments have been completed and initial testing shows that under steady glass flow rates there exists a critical flow rate below which wicking occurs. Future experiments will focus on the investigation of several factors to determine their effects on wicking. Variations in operating parameters such as glass temperature, pouring temperature, and glass flow rate will be studied to quantify their effects on wicking. 
Physical property parameters such as free stream thickness contact angle, capillary deflection, viscosity, and surface tension will also be measured. Variations to the pour spout geometry will be investigated to determine their effects on wicking. Changing the pour spout cut back, angle will test the effect of the geometry of the knife edge. Both steady and transient flows will be used for all the test cases. 


\subsection{INTRODUCTION}

Vitrification is the process of capturing radioactive waste in glass. The Savannah River Site's (SRS) Defense Waste Processing Facility (DWPF) is one of the facilities using the vitrification technology to treat and immobilize radioactive waste. The work being performed at FIU-HCET in support of the Tank Focus Area (TFA) Technology Implementation Manager (EM-50) and the Savannah River Technology Center (SRTC) consists of three phases. Phase 1 involves the assembly, construction, and testing of a melter capable of supplying molten glass at operational flow rates over a break-off point knife edge. Phase 2 evaluates the effect of glass and pour spout temperatures as well as glass flow rates on the glass flow behavior over the knife-edge. Phase 3 will identify the effects on wicking that result from varying the knife edge diameter and height as well as changes to the back-cut angle of the knife edge. The project is currently in its second year of operation.

The Savannah River Site's (SRS) Defense Waste Processing Facility (DWPF) is one of the facilities using the vitrification technology to treat and immobilize radioactive waste since March 1996. However, the operation has been marked by extreme difficulty in maintaining a stable pouring process. There have been flow fluctuations accompanied by an unusual flow phenomenon, termed "wicking." In this situation, the falling glass stream wavers and departs from a normal vertical trajectory. The pour spout and associated hardware connecting it to the canister have been coated and often plugged with glass.

The objective of the project is to investigate the pouring behavior of molten glass over a pour spout knife edge. Experiments are run using simulant glass containing the same chemical formulation as the radioactive sludge glass, but without radioactive contaminants. The purpose of these tests is to obtain actual glass data that, when combined with previous cold data from other fluids, will provide an overall understanding of the physics of liquids flowing over a pour spout and knife edge. A specific objective is to verify computational fluid dynamics (CFD) models with a range of liquid data with particular emphasis on glass so as to provide confidence in use of these CFD models for designing a new improved pour spout for the DWPF melter. The work to be performed at FIU-HCET includes assembling the melting and pouring system that mimics the DWPF melter and determining the key parameters that may influence wicking. Information from the FIU-HCET melter tests will lead to better operating guidelines for the DWPF melter so as to avoid wicking.

During FY98, a bench-scale melter complete with pour spout and a knife edge was designed and assembled at FIU-HCET. Initially, the system was tested with glycerine. Subsequently, glass provided by SRS was used for experimentation. Flow visualization tests were performed with the melter in FY98 to investigate the pouring behavior of molten glass over a pour spout model simulating a DWPF pour spout of the original design. Simulant glass containing the same chemical formulation as sludge glass but without radioactive contaminants was used in the tests. All the tasks and milestones mentioned in the PTP for the project were accomplished.

The project completed its second year, and this document reports the tasks and milestones that were accomplished during the 1998 fiscal year. 


\subsection{ACTIVITIES COMPLETED FY98}

\section{TASK 1. CONSTRUCT THE MELTER AND INSTALL THE FURNACE}

The major components for this task were the construction of the melter and the installation of the furnace. Constructing the melter includes fabricating and assembling the glass chamber, raising section, pouring spout, and knife edge configuration. The furnace installation included setting up heating elements, insulation, and the multizone temperature control system. Installation of the data acquisition system, the pouring flow rate control system, and the visualization system were also part of this task.

The project commenced in November 1996. On November 5-6, FIU-HCET personnel visited the Savannah River Site's Defense Waste Processing Facility (DWPF) to identify and address concerns regarding glass pouring efficiency. In addition, the Technical Development Summary was completed and reviewed by Dr. John Plodenic from SRS. Comments were received and the necessary modifications have been carried out. A literature search was initiated to investigate

glass properties with respect to pouring, chemical characteristics, and heat transfer. Contact personnel were identified for effective communication between FIU and SRS scientists. The project team began to develop the design criteria for a full-scale glass pouring facility. Power and space requirements were identified and implemented. The Savannah River Site was revisited for the identification and acquisition of potential surplus melter components for use in the development of the experimental facility at FIU-HCET. Eric Hansen from SRS was identified as the main point of contact for the project.

Based on the approved design, the horizontal section of the melter was first fabricated, followed by the machining of the connecting flanges. The pour spout was redesigned and sent to Westinghouse Savannah River Company (WSRC) for review. Modifications to the pouring section view window were made according to the suggestions of $\mathrm{H}$. Guerrero at WSRC.

Pyrotech Services was chosen to provide the heating unit with two heating elements in the roof section of the melter, one thermocouple location between Zone 3 and Zone 4 opposite the view port, and structures to support the knife edge section just above the view port. Pyrotech Services sent an engineer to FIU-HCET to discuss the details of the furnace design and installation, including temperature control methods, heating element location, and melter and furnace supporting constructions. The furnace was scheduled to be delivered to FIU-HCET by the end of January, and it was decided that the installation of the furnace by engineers from Pyrotech will then take place.

A simulating system for pressurizing feed and flow rate control was designed and set up as shown in Figure 1. Initial tests using water as the simulating liquid and air as the pressuring medium were conducted. Results showed that the flow rate of water could be controlled using the gas flow system. 


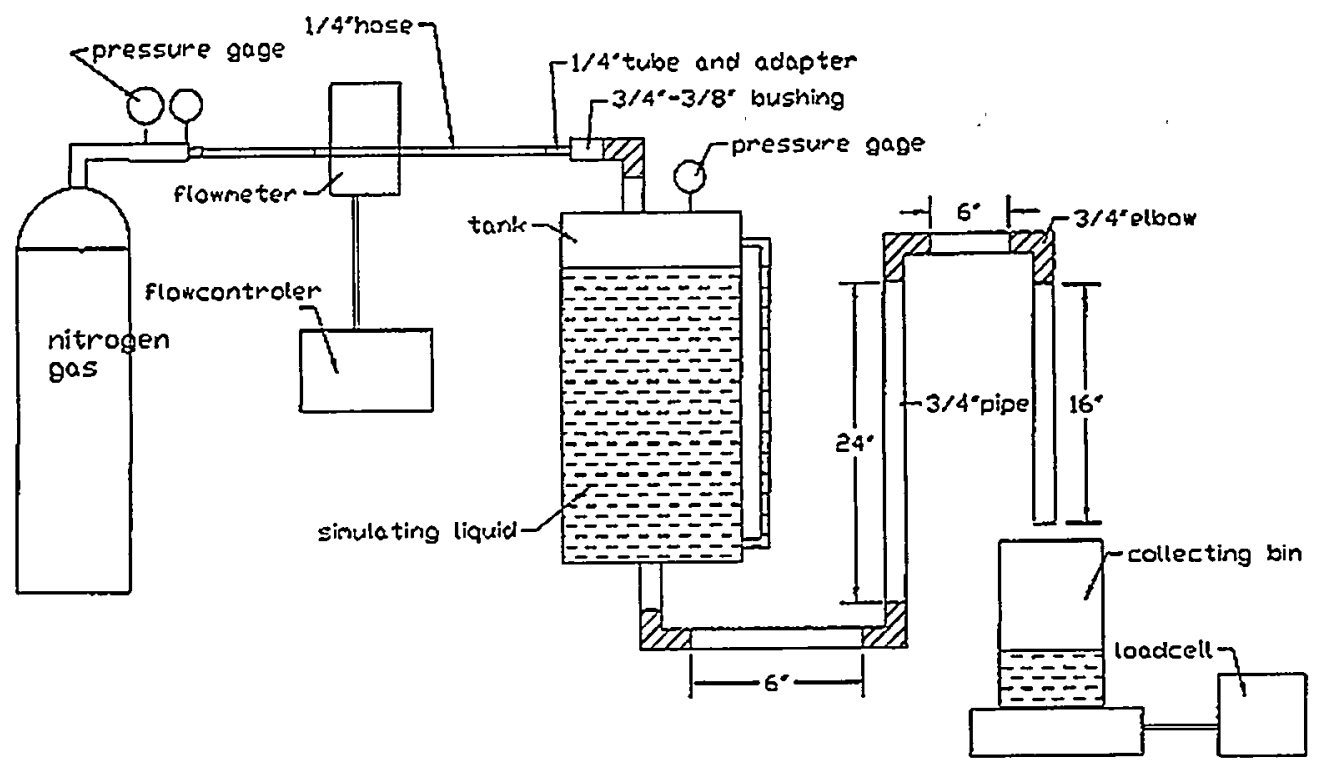

Figure 1. Flow control simulating system.

The visualizing system was set up as shown in Figure 2 and tested. The system includes four digital cameras, a two-color simplex multiplexer, a digital video caliper, a VCR, and a monitor. It can take four different views and record the four views on one video tape. The caliper can measure the length and width of a selected object.

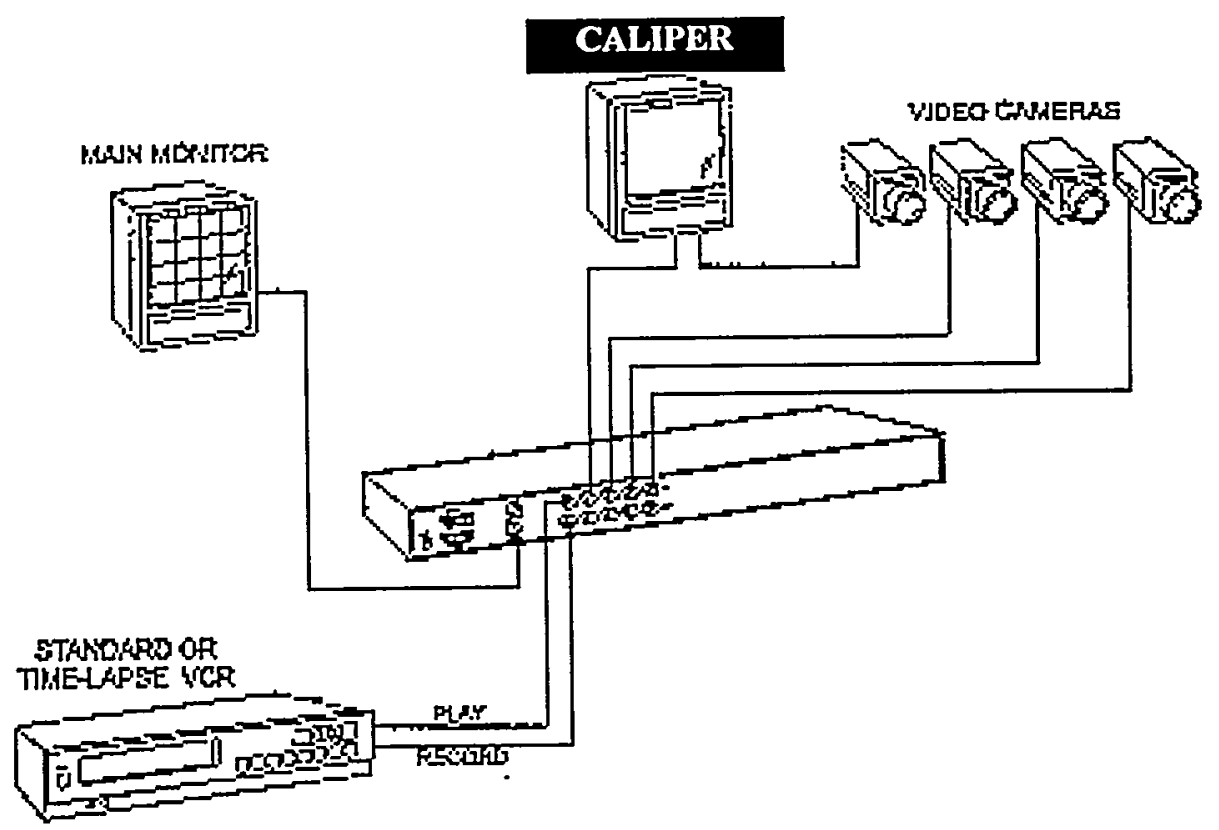

Figure 2. Visualizing system. 
In February 1998 the furnace and the control panel have been delivered to FIU-HCET by Pyrotech Services. The furnace was then set up. Furnace delivery and setup pictures are shown in Appendix A. The power line and control loop were connected and a representative from Pyrotech Services gave a brief demonstration and training session on how to operate and disassemble the furnace.

\section{TASK 2. TEST AND EVALUATE THE MELTER AND CONTROL SYSTEMS}

Initial tests were performed with simulated materials such as glycerin or other viscous fluids to evaluate the performance of the pouring flow rate control system and related instrumentation. The testing results provided calibration curves for the gas flow system.

The furnace was turned on three times, and the temperature of Zones 1,3 , and 4 reached a stable $1150^{\circ} \mathrm{C}$ satisfying the design criteria. The time-temperature curves for the three times are shown in Figure 3.

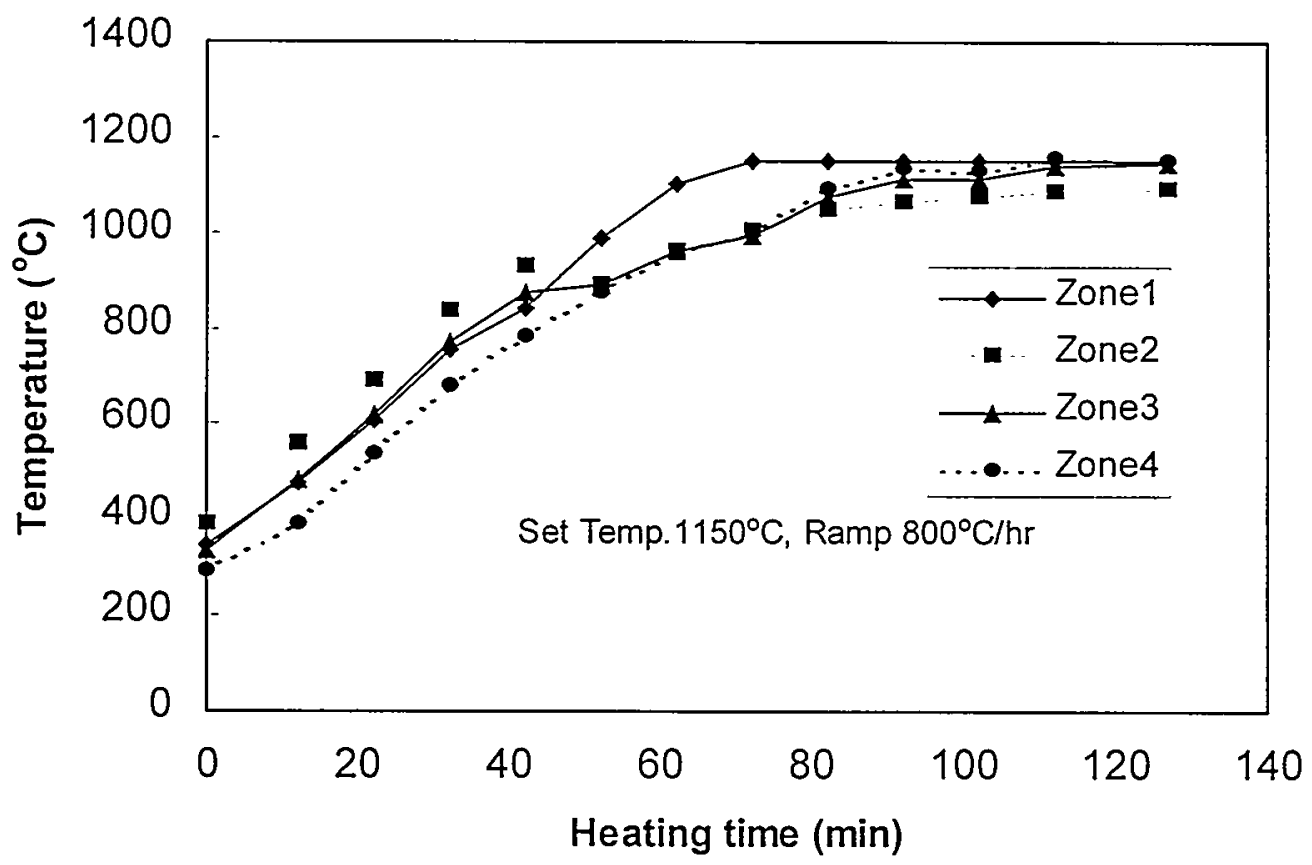

Figure 3. The relation of heating time and temperature.

Preliminary tests for pressuring feed and flow rate control were then conducted. Water and glycerin were used as simulating liquid and nitrogen gas as pressuring medium. It was found that the flow rate of water or glycerin pouring from the pour spout was a linear function of the quantity of nitrogen gas fed into the chamber as shown in Figure 4 and Figure 5. 


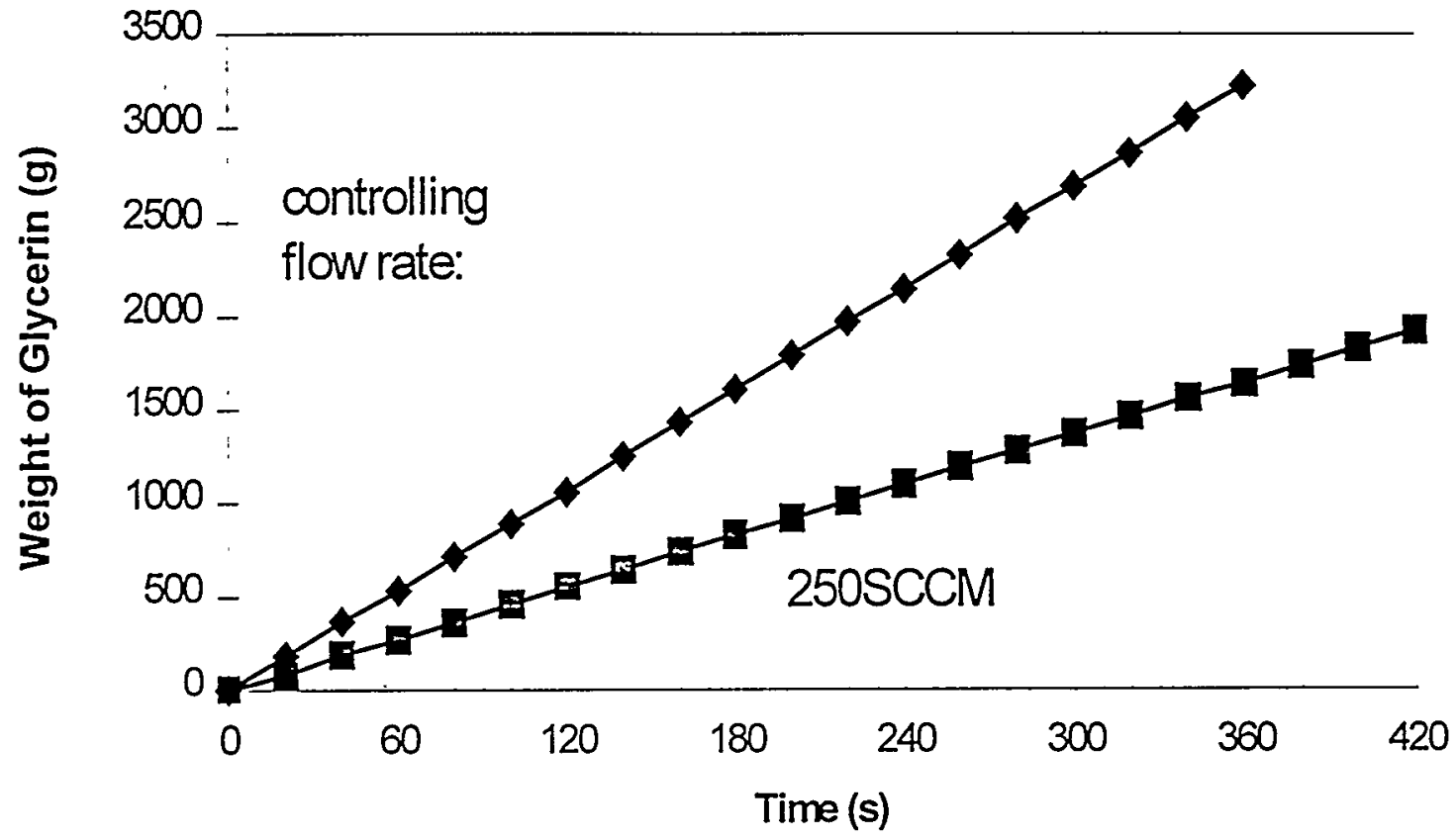

Figure 4. Weight of glycerin pressed out of tank by nitrogen (nitrogen pressure: 20psi).

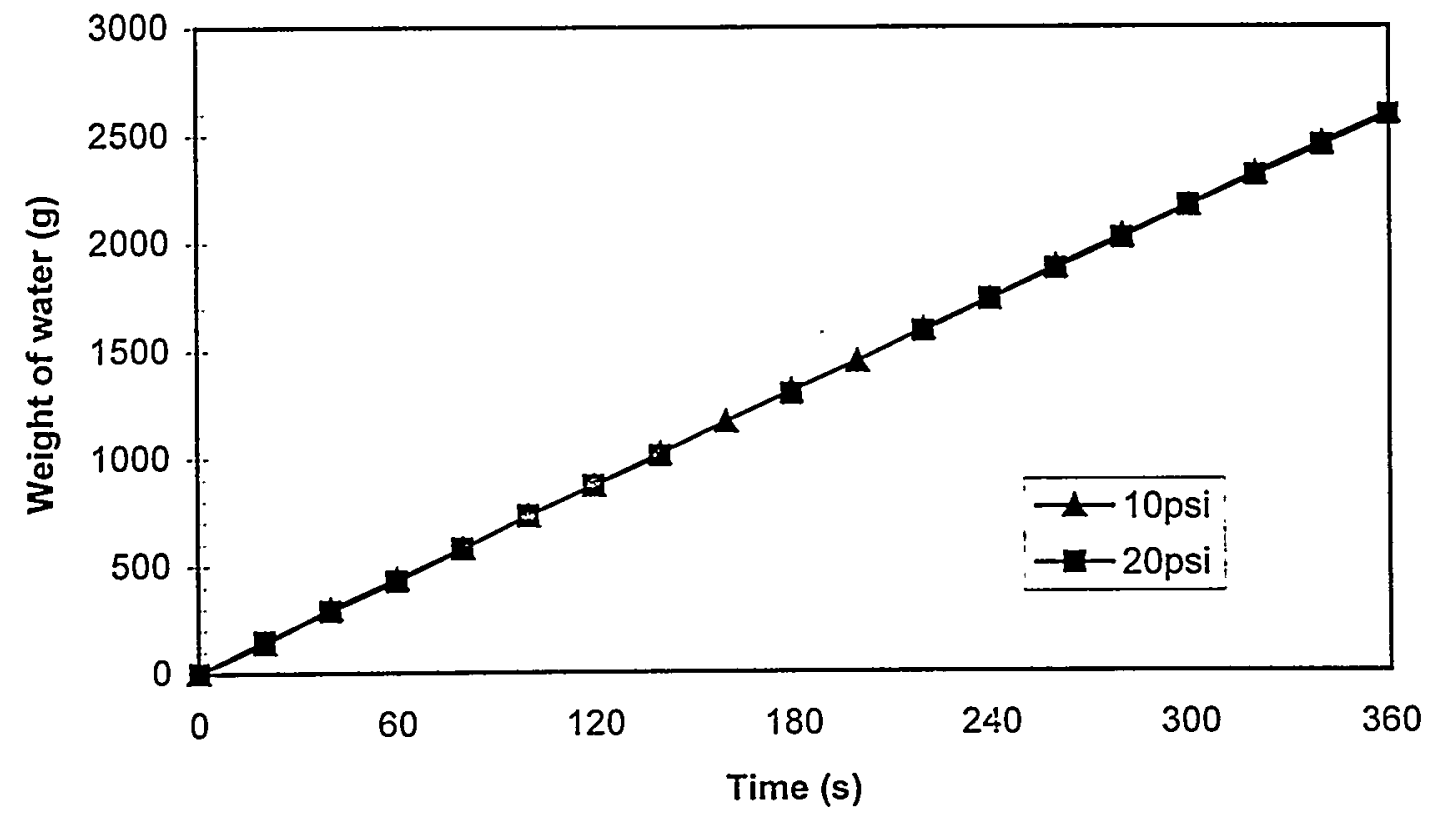

Figure 5. Weight of water pressed out of tank by nitrogen gas (controlling rate: 500 SCCM). 
When the heating capacity of the furnace was checked and assembled, it was discovered that the heating element in Zone 2 was broken (Appendix B). The service engineer from Pyrotech Services replaced the element and added a new slot in the control panel for recording and displaying the temperature of the molten glass in the chamber and the temperature of the pouring section.

The melter chamber was then welded. After welding, the chamber was checked by using compressed gas with a pressure up to $20 \mathrm{psi}$. There were several leaks located in some weld seams. These location were rewelded to stop the leakage. The chamber was placed in the furnace, and the dimensions of the horizontal section were adjusted to fit the furnace chamber.

The LabVIEW system was set up and programmed. The six temperature signals from the chamber and pouring sections and the one signal from load cell can be recorded by a computer. The collecting bin for molten glass along with a loading cell was procured.

By April 1998, the melter (including chamber and pouring section) had been assembled as shown in Figure 6.
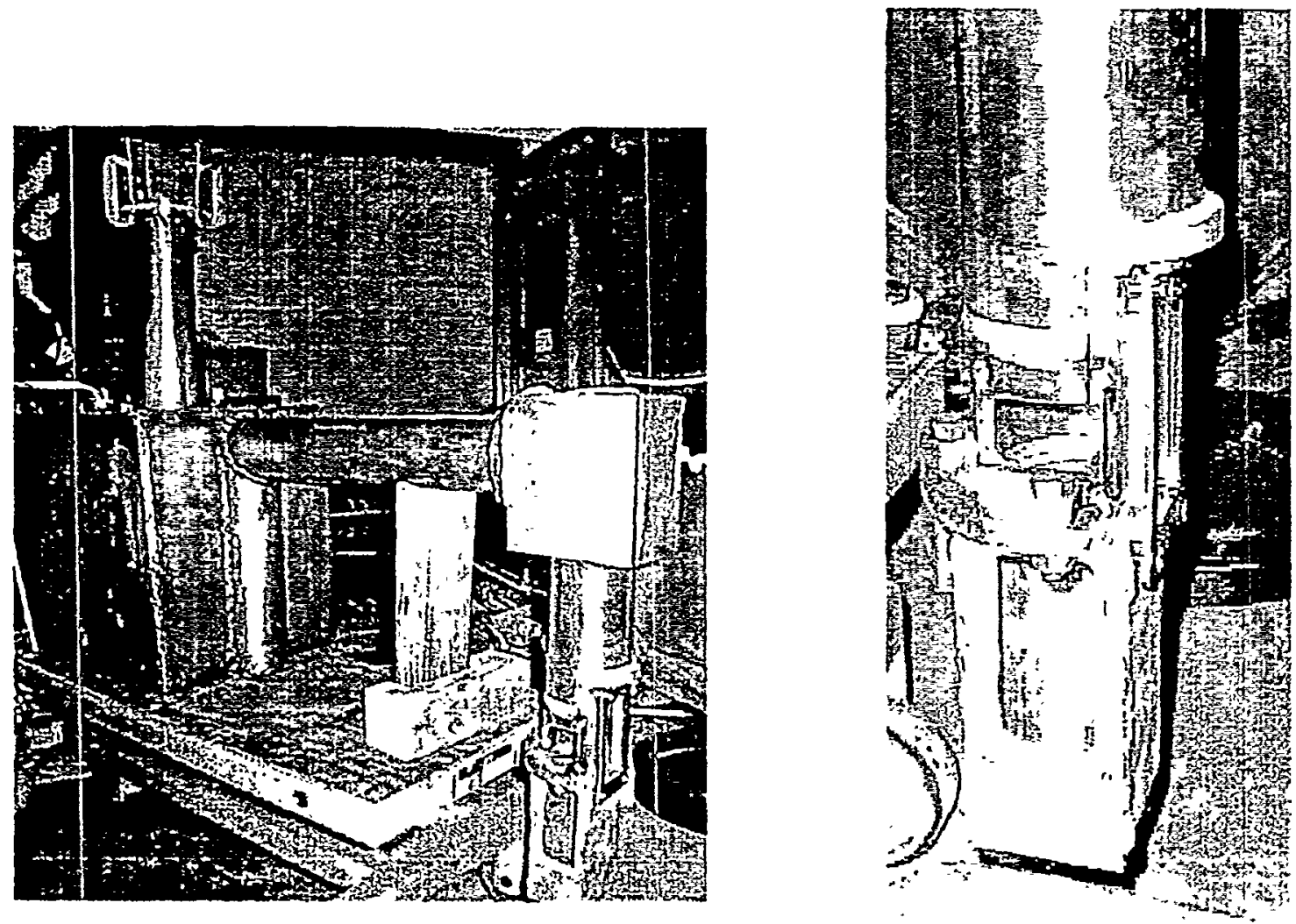

Figure 6. The melter and knife edge. 
There was a problem with the gasket of the feeding flange, but it was resolved by using the insulation material. Further leak testing was performed using nitrogen, and no leaks were found in the melter or the top feeding flange. The melter was then tested using glycerin as the simulant. The glycerin flowing through the knife edge could be observed clearly (Figure 7). The flow of glycerin was smooth, steady, and inclined toward the wall of knife edge. When the flow rate of nitrogen fed into the melter was set to 500 SCCM (maximum flow rate), the flow rate of glycerin pushed out of the melter was $80 \mathrm{lb} / \mathrm{h}$. Based on density calculations, it was inferred that the maximum flow rate of molten glass could reach more than $500 \mathrm{lb} / \mathrm{h}$ at a temperature of $1150^{\circ} \mathrm{C}$. Also, the LabVIEW program has been modified to obtain the flow rate reading from the weight of the molten glass and record it with the other data.

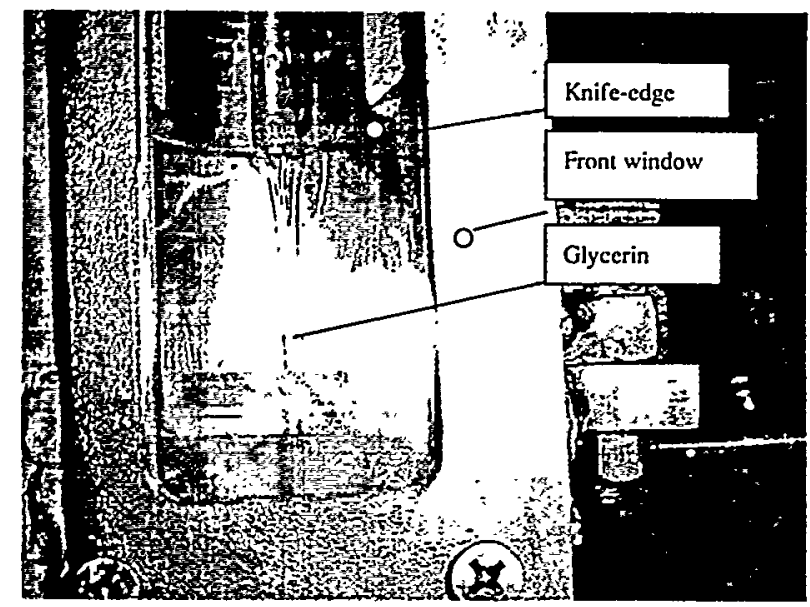

a) Front view

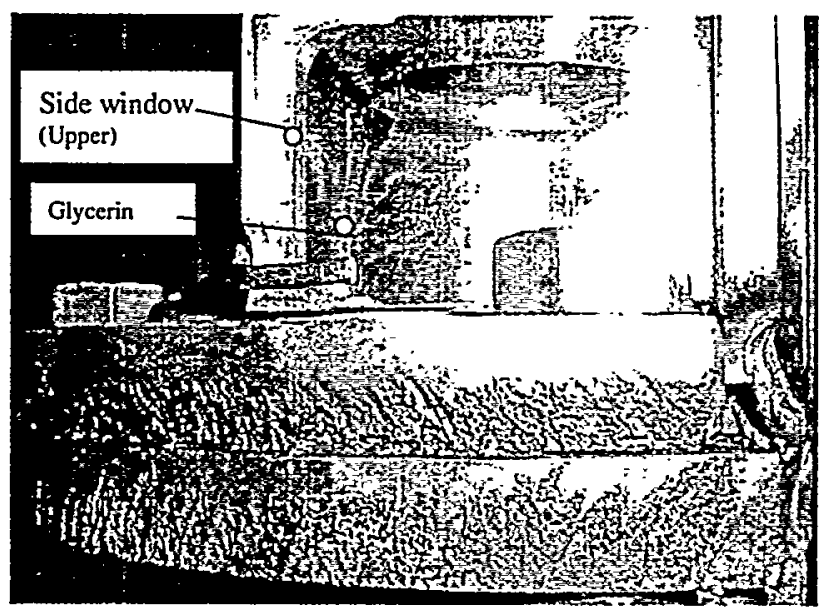

b) Side view (upper)

Figure 7. Glycerin flows through the knife edge.

At this stage of the project, the following items of interest concerning the testing system were reviewed and confirmed. The maximum working temperature for the $\mathrm{K}$-type thermocouple is $1250^{\circ} \mathrm{C}$, and the accuracy of the $\mathrm{K}$-type thermocouple is $2.2^{\circ} \mathrm{C}$. The thermocouples must touch the surface of the melter and knife edge for accurate readings. The pressure in the chamber is not controlled but can be detected with a pressure gauge. The flow rate of the molten glass is controlled by controlling the flow rate of nitrogen gas fed into the melter with a flow meter.

By May 1998, the project had fallen behind schedule, and the glass flow had not been tested yet. The melter chamber was again tested for leaks one last time using glycerin as a simulant. The quartz windows had been fitted on the furnace pouring section. The furnace with the melter installed was preheated to $600^{\circ} \mathrm{C}$. The four Micro-Mac ${ }^{\circledR} 7 \mathrm{HAD}$ COD Color Digital Cameras were installed, and the T-Q/DMZR Digital Video Caliper, a VCR, and a color monitor were connected with the cameras. Through the quartz windows, the visualization system can take pictures and record the flow conditions of the glass pouring. The feeding system, including nitrogen gas, pressure regulator, master flow meter, and controller, had already been set up and connected to the melter. The load cell was rebuilt to minimize the instability of the collecting bin. The calibration of the load cell has been conducted using water and a balance with the accuracy of $0.0002 \mathrm{lb}$. The LabVIEW data acquisition system was connected to the thermocouple of the furnace and the load cell and the program modified to minimize the data 
fluctuation. The power for the crusher was connected, and some glass was crushed. Different size glass fragments were obtained by adjusting the opening of the feeding port.

Toward the end of May 1998 when the furnace was being heated to the required temperature of $1150^{\circ} \mathrm{C}$, the heating element in Zone 2 broke resulting in shutdown of the experiment. Pyrotech was contacted for repairs. The furnace manufacturer redesigned and sent the new heating elements. When the melter was taken out of the furnace, shrinkage of elements was detected. The shrinkage had caused undue strain on the elements resulting in their severance. The new heating elements consist of three coils around the connecting block of pouring spout and horizontal section, which were made of a $\phi 2.2 \mathrm{~mm}$ APM wire, instead of $\phi 1.8 \mathrm{~mm}$ that reduced the surface load from $4.55 \mathrm{w} / \mathrm{cm}^{2}$ to $2.53 \mathrm{w} / \mathrm{cm}^{2}$.

The experimental system, including temperature control, visualization, and flow rate control systems, has been set up (Figure 8), and preliminary tests have been conducted on the visualizing system and LabVIEW Data Acquisition system during furnace preheating. The knife edge can be taped clearly from the front and side windows. The load cell has been modified to improve its stability. The temperature data acquired by LabVIEW was fluttering, so high-accuracy thermocouples and a metal-shielded extension were ordered to improve the data accuracy.

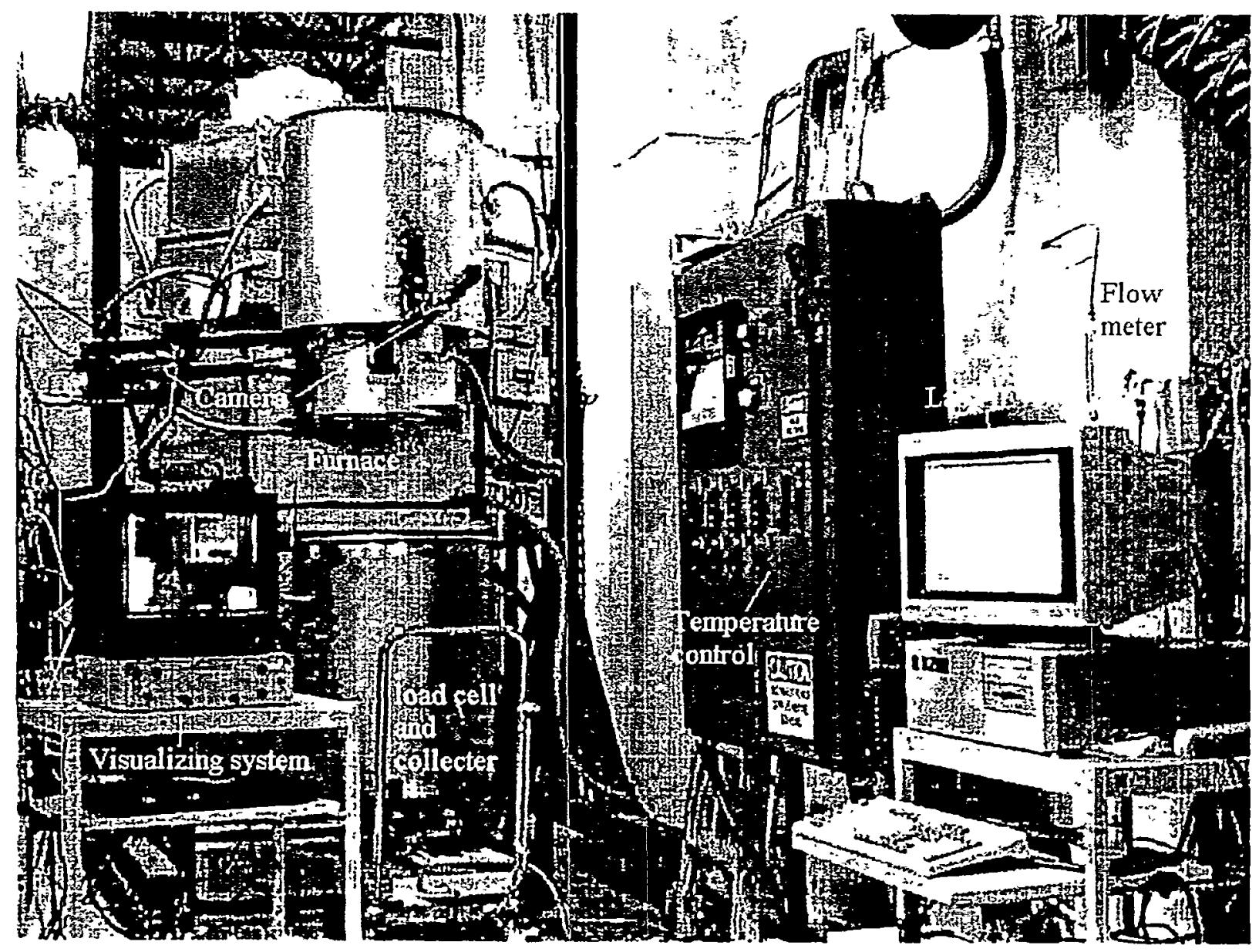

Figure 8. Complete experimental system setup. 
In June 1998, after the new coils were installed, the furnace was preheated one more time. The new coils broke again when the temperature reached $900^{\circ} \mathrm{C}$. Pyrotech (furnace company) then decided to inspect the broken coils on-site and to refabricate and reinstall the Zone 2 heaters. Additionally, Pyrotech promised to supply new heating elements for Zones 3 and 4. Each of the new heating elements have $1.1 \mathrm{~kW}$ power output instead of $0.8 \mathrm{~kW}$, and one more unit of $1.1 \mathrm{~kW}$ was added in Zone 3 to increase the heating rate of Zones 3 and 4 . A new temperature measuring point was also added on the furnace to measure the temperature at the bottom side of the horizontal section.

After all the repairs, the furnace was put together and was loaded with $250 \mathrm{lbs}$. of glass in July 1998. The furnace was fired up, and when the temperature inside the melter reached $1000^{\circ} \mathrm{C}$, element in Zone 2 broke again, resulting in an unsuccessful run. During the first run with the molten glass, a leak was also discovered in the top feeder flange. It was taken care of by replacing the gasket and bolting down the flange instead of using C-clamps. The gasket is rated for $550^{\circ} \mathrm{C}$. The replacement of the Zone 2 element was completed by Pyrotech furnace company on July 20,1998 . The furnace was loaded with approximately $180 \mathrm{lbs}$. of glass, and the first successful run was completed on July 21, 1998. The experiment was recorded using the cameras and a video tape. Video tapes of the experiment were handed to SRTC personnel. Figure 9 is the schematic of the film thickness measurement data. Figure 10 shows the temperature in the melter bath and the weight increment of pouring glass during the experiment.

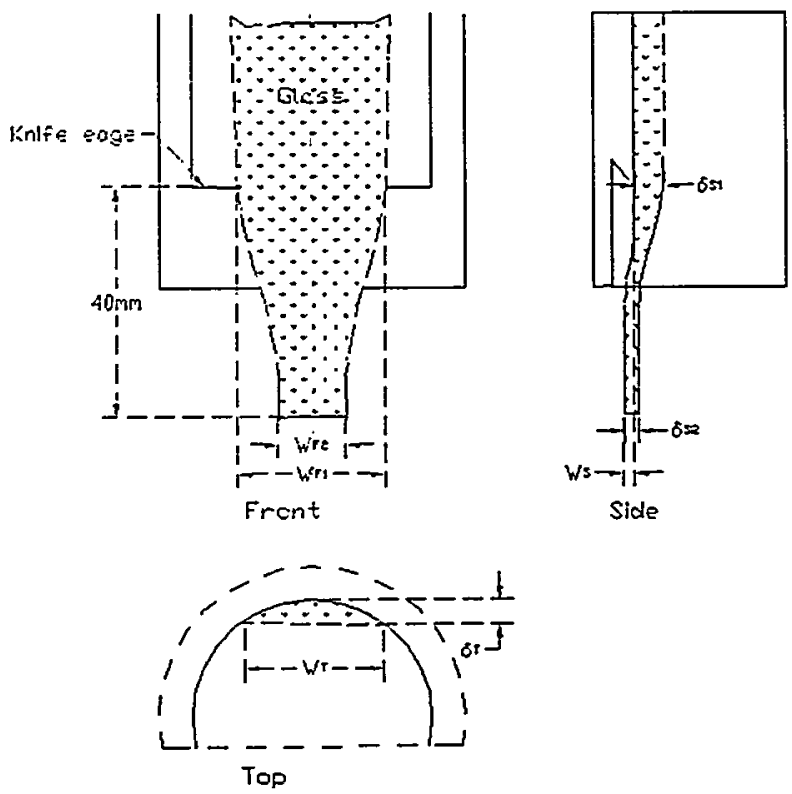

Figure 9. Schematic showing the glass film measurements to be recorded during the experiments. 


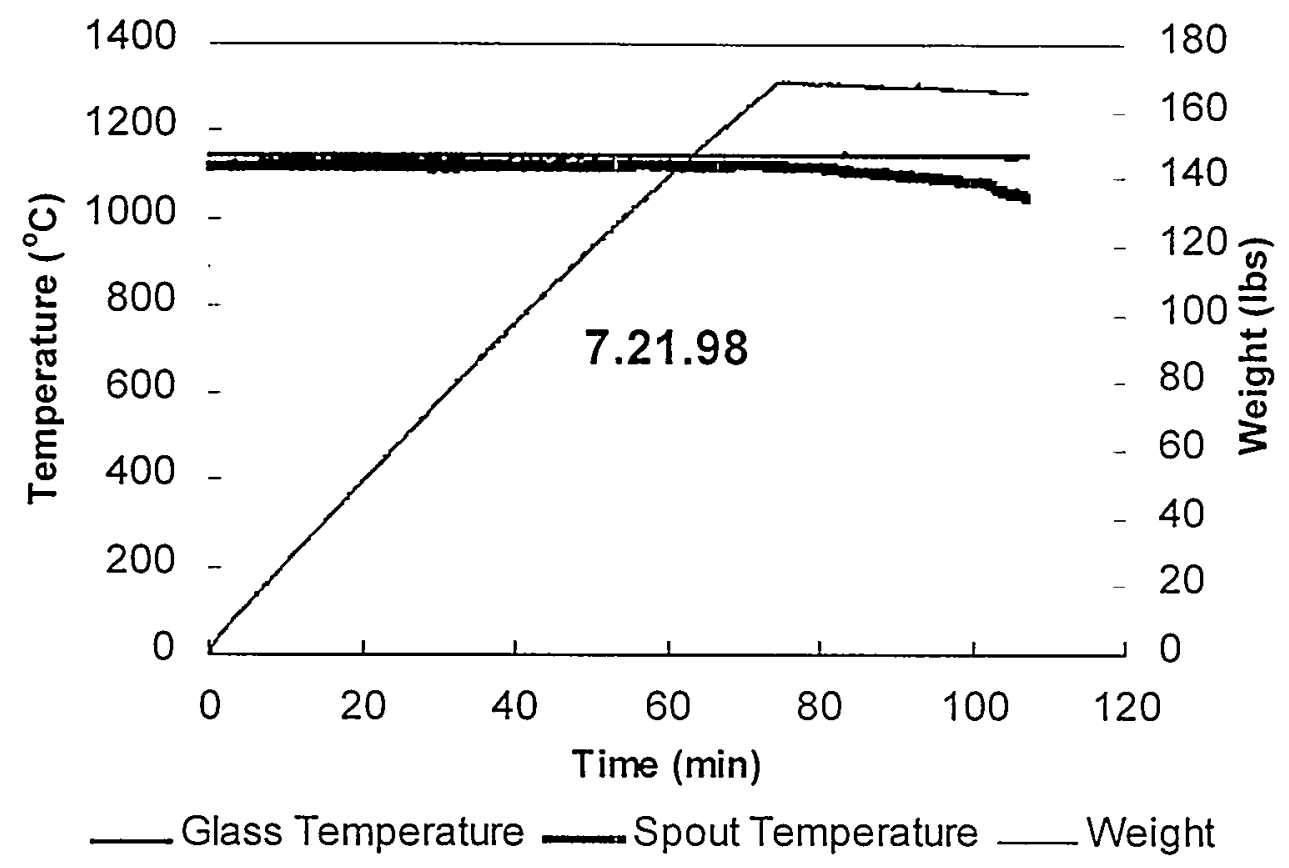

Figure 10. Weight increment and melter temperature during glass pouring test done on $7 / 21 / 98$.

A mid-year review meeting was held with SRS personnel at FIU-HCET on July 22, 1998, regarding a progress update on the glass pouring project. The furnace was not demonstrated in an operating mode; however, SRTC personnel were very pleased with the video recording of the experiment done on the previous day (7/21/98).

The following is the summary of discussions that focused on means of improving data collection and smooth operation of the furnace.

- SRTC was interested in transition flows. From experience, disturbances in the glass flow are the prime cause of wicking. A pressure transducer along with mass flow controller's $0-5 \mathrm{~V}$ input using LabVIEW will give a quantitative handle on wicking based on disturbances to the glass flow. Hector suggested that FIU-HCET try a sinusoidal flow rate with a time period of $10 \mathrm{~s}$.

- From the modeling viewpoint, there is a need for an exact thermal profile on the down spout. This will require putting an auxiliary heater and an additional thermocouple (TC) at the pour spout. Also, the TCs need to be calibrated and monitored at regular intervals for the drift.

- FIU-HCET will monitor the glass level in the melter by blowing air through the melter.

- For better quality images, use of blue filters was recommended. Vendor Inno Vision Inc. was suggested for getting a high-end camera.

- SRTC would like data in forms of digital images, preferably on the web-site from which they can be downloaded. Also, FIU-HCET will provide a superimposed reference point on the pictures. 
- A suggestion was made to realign the top camera and center it on the pour spout. FIU-HCET will make sure once the furnace is taken out for cleaning.

- Tests will be done at three melter temperatures: $1000^{\circ} \mathrm{C}, T_{\eta_{\text {mid }}}$ and $1150^{\circ} \mathrm{C} . T_{\eta_{\text {mid }}}$ is the temperature at which the viscosity is the average of the upper and lower values.

- Surface tension and viscosity measurements on the glass sample can be done at Alfred State University. Dr. Bickford can get discounted rates.

- There were also discussions on investigating the effect of varying the pour spout geometry on wicking. Effect of an eroded pour spout knife edge and the effect of accumulated deposits behind the knife edge need to be studied.

- A suggestion was made that glass pouring project personnel should visit Clemson and experience firsthand industrial-size glass melter operations.

- The furnace should be back in oepration by the week of $8 / 3 / 98$. FIU-HCET will run base tests at three temperatures $1000^{\circ} \mathrm{C}, T_{\eta_{\text {mid }}}$, and $1150^{\circ} \mathrm{C}$ for 6 different flow rates from $50 \mathrm{lbs} / \mathrm{hr}$ to $300 \mathrm{lbs} / \mathrm{hr}$. Glass pouring runs are also planned for SRTC personnel who will visit FIUHCET for scoping tests.

\section{TASK 3. BASELINE RUNS}

After the first successful run, the melter was shut down as the vent (offgasing) got plugged. The pressure build-up from offgasing forced the molten glass into the cold pour spout. The melter was taken out of the metal casing and cleaned using an air hammer and a sand blaster. Zone 3 and Zone 4 heater elements were also replaced, and the furnace was reassembled. New quartz windows were installed on the metal casing of the melter on the outside. Previously, they were mounted on the furnace itself. This made them more accessible. A pressure transducer was installed to monitor the pressure in the melter head-space. At the recommendation of SRS, various filters were tried with the $\mathrm{CCD}$ camera to distinguish the metal knife edge clearly from the molten glass at pour spout temperatures $\left(1050^{\circ} \mathrm{C}-1150^{\circ} \mathrm{C}\right)$, but the results were not promising. Calibrated thermocouples were ordered from Omega.

The glass film thickness data for the baseline runs are summarized in Table 1. Copies of the videos of the experiments were handed over to WSRC personnel. WF is the glass film thickness measured.

Table 1.

Glass film thickness data for the baseline runs

\begin{tabular}{|c|c|c|c|c|c|c|c|}
\hline \multirow[t]{2}{*}{ Exp. } & $\begin{array}{c}\text { Glass } \\
\text { Temperature }\end{array}$ & $\begin{array}{l}\text { Knife-edge } \\
\text { Temperature }\end{array}$ & \multirow{2}{*}{$\begin{array}{c}\text { Glass Flowrate } \\
\text { lbs/hr }\end{array}$} & $W_{F}$ & $W_{T}$ & $\mathrm{X}$ & $Y$ \\
\hline & \multicolumn{2}{|c|}{${ }^{\circ} \mathrm{C}$} & & \multicolumn{4}{|c|}{$\mathrm{mm}$} \\
\hline $\mathrm{A} 1$ & 1150 & 1150 & 43.5 & 1.9 & 37.0 & 9.0 & 1.8 \\
\hline $\mathrm{A} 2$ & 1150 & 1150 & 103.5 & 2.8 & 41.0 & 9.9 & 2.8 \\
\hline $\mathrm{A} 3$ & 1150 & 1150 & 159.0 & 4.4 & 45.0 & 9.0 & 3.4 \\
\hline A4 & 1150 & 1150 & 200.0 & 7.2 & 53.4 & 8.9 & 3.8 \\
\hline
\end{tabular}


Table 1.

Glass film thickness data for the baseline runs (Continued)

\begin{tabular}{|c|c|c|c|c|c|c|c|}
\hline \multirow[t]{2}{*}{ Exp. } & $\begin{array}{c}\text { Glass } \\
\text { Temperature }\end{array}$ & $\begin{array}{l}\text { Knife-edge } \\
\text { Temperature }\end{array}$ & \multirow{2}{*}{$\begin{array}{c}\text { Glass Flowrate } \\
\mathrm{lbs} / \mathrm{hr}\end{array}$} & $W_{F}$ & $W_{T}$ & $\bar{x}$ & $\mathrm{Y}$ \\
\hline & \multicolumn{2}{|c|}{${ }^{\circ} \mathrm{C}$} & & \multicolumn{4}{|c|}{$\mathrm{mm}$} \\
\hline A5 & 1150 & 1150 & 300.0 & 11.2 & 65.5 & 9.0 & 4.1 \\
\hline $\mathrm{B} 1$ & 1062 & 1053 & 145.0 & 10.6 & 59.0 & 9.6 & 3.9 \\
\hline B2 & 1056 & 1047 & 290.0 & 12.6 & 56.3 & 8.8 & 4.8 \\
\hline B3 & 1100 & 1090 & 143.0 & 6.4 & 20.3 & 9.5 & 3.2 \\
\hline B4 & 1103 & 1100 & 295.0 & 11.2 & 46.0 & 11.2 & 4.5 \\
\hline $\mathrm{Cl}$ & 1155 & 948 & 150.0 & 6.4 & 46.0 & 7.9 & 4.0 \\
\hline $\mathrm{C} 2$ & 1162 & 1062 & 136.0 & 5.0 & 45.7 & 8.3 & 3.4 \\
\hline D1 & 950 & 1065 & 150.0 & 11.9 & 70.0 & 9.1 & 4.6 \\
\hline
\end{tabular}

One of the objectives of the baseline runs was to ascertain the changes in glass film thicknesses with respect to change in process parameters such as glass flow rate, glass temperature, knifeedge temperature, and the temperature differential between actual glass and the knife edge.

\section{Variation of Glass Flowrate (A1-A5)}

Figure 11 shows the change in the front glass film thickness $\left(\mathrm{W}_{\mathrm{F}}\right)$ with changes in the glass flow rate from $50 \mathrm{lbs} / \mathrm{hr}$ to $350 \mathrm{lbs} / \mathrm{hr}$. Figure 12 shows the change in top glass film thickness $\left(\mathrm{W}_{\mathrm{T}}\right)$ with increasing glass flowrate. Both $W_{F}$ and $W_{T}$ increase with increase in glass flowrate. Figure 12 shows the deflection $(X)$ of the glass stream measured $25 \mathrm{~mm}$ vertically below the knife edge. The glass film thickness measured from the side view port is $Y$ at $25 \mathrm{~mm}$ below the knife edge. The glass flowrate has negligible effect on the glass film deflection $(X)$ from the knife edge as shown in Figure 13. The glass film thickness (Y) did increase with increase in the glass flow rate (Figure 13). 


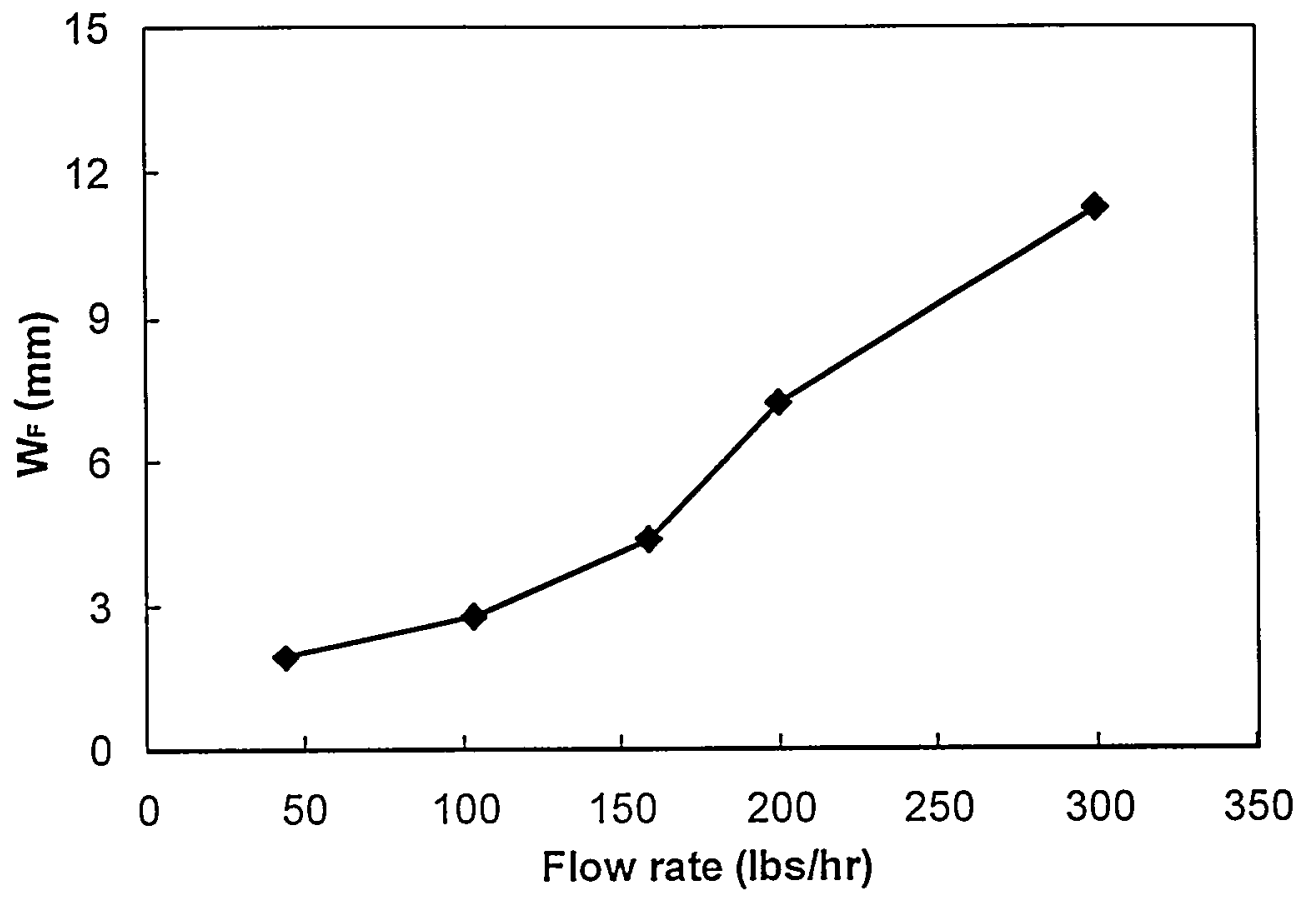

Figure 11. Increase in $W_{F}$, front glass film thickness with increase in glass flowrate.

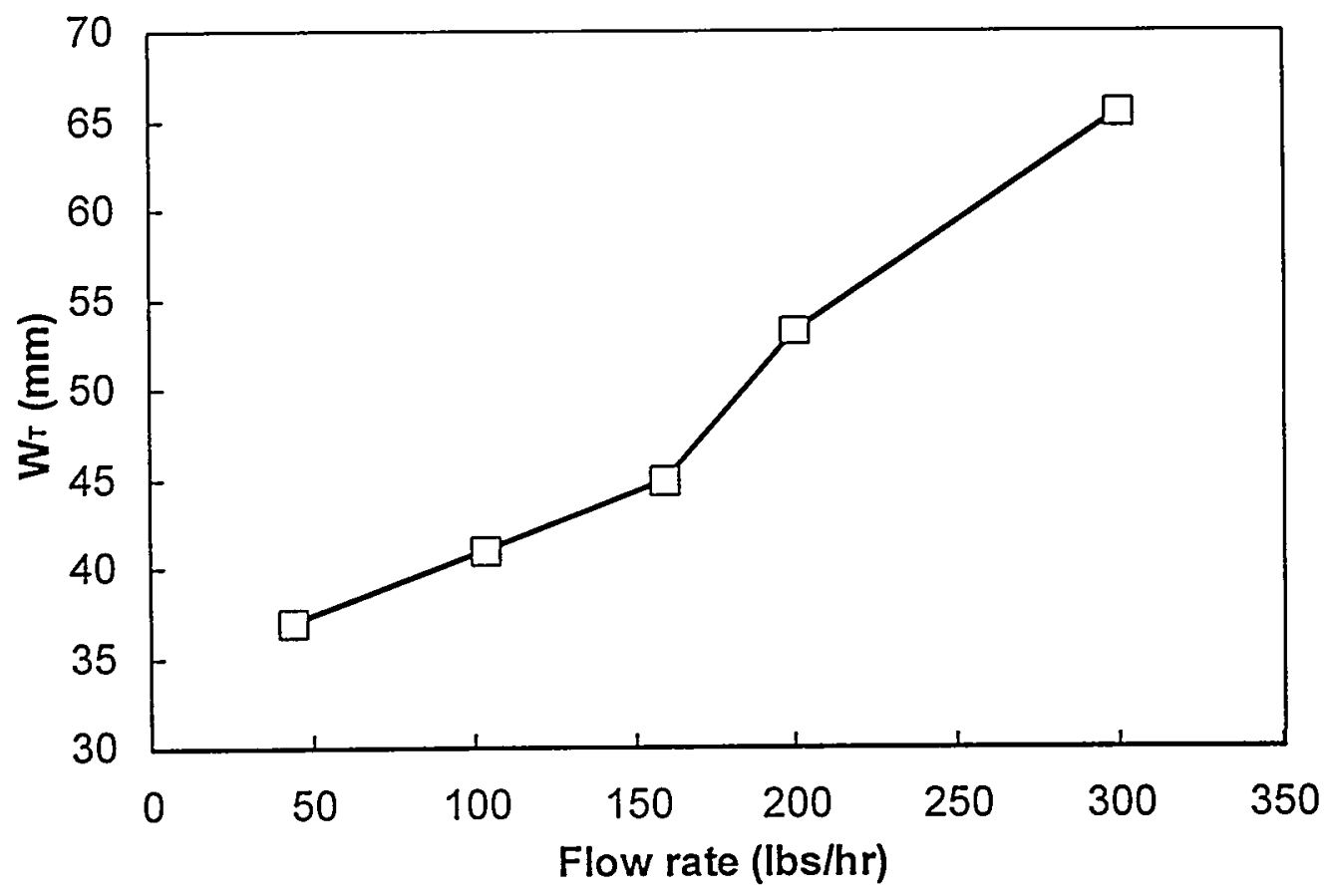

Figure 12. Increase in $W_{T}$, top glass film thickness with increase in glass flowrate. 


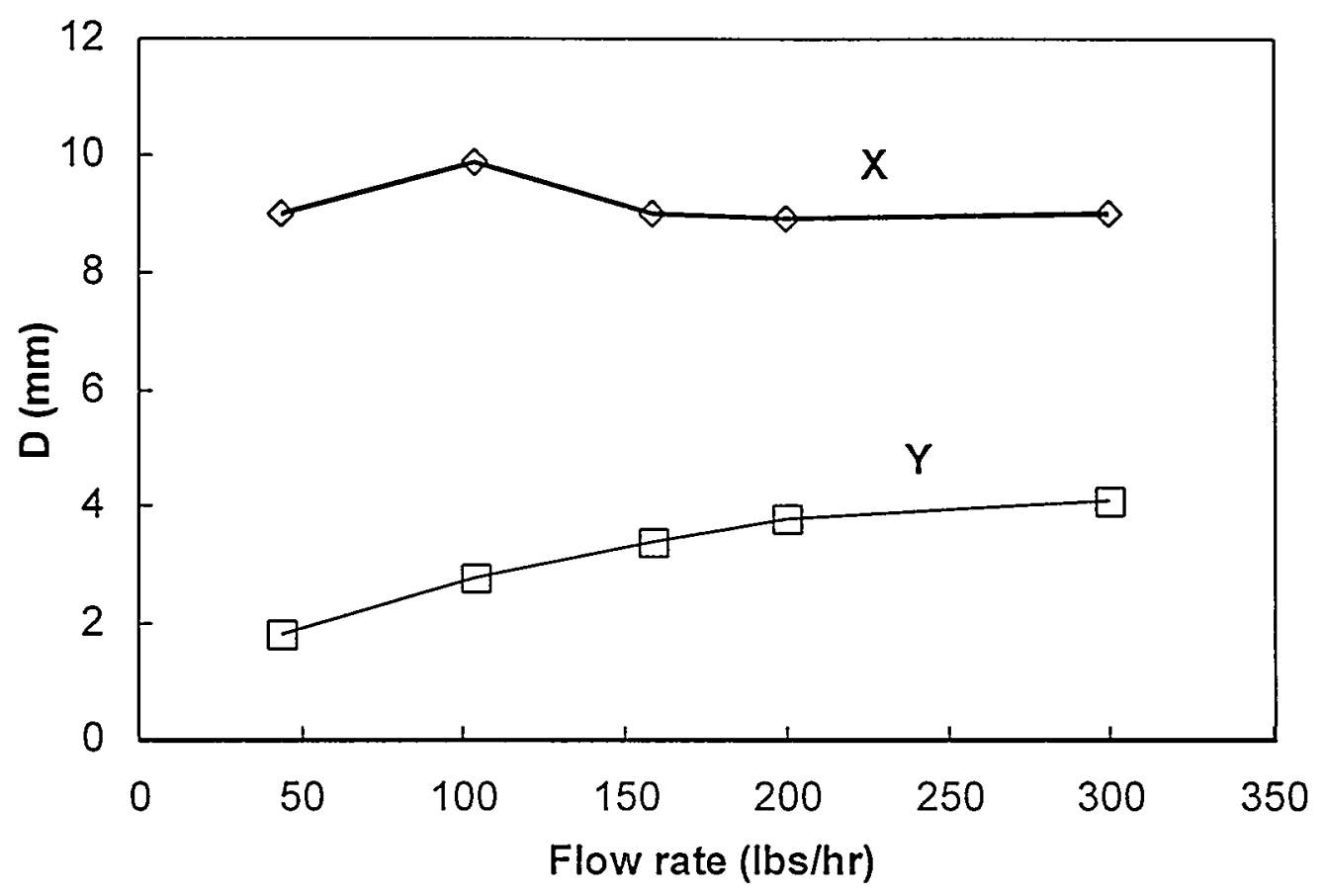

Figure 13. Increase in $\mathrm{Y}$, glass film thickness with increase in glass flowrate.

\section{Variation of Glass Temperature and Pour Spout Temperature (B1-B4, A4, A5)}

To ascertain the effect of glass temperature and the pour spout temperature, 6 experiments were done at two flow rates of $150 \mathrm{lbs} / \mathrm{hr}$ and $300 \mathrm{lbs} / \mathrm{hr}$. The temperatures of glass and pour spout were 1050,1100 , and $1150^{\circ} \mathrm{C}$, respectively. Figures $14-16$ show the respective film thicknesses data. $\mathrm{W}_{\mathrm{F}}$ showed a decrease with increasing temperature. However, $\mathrm{W}_{\mathrm{T}}$ was minimum at the intermediate temperature of $1100^{\circ} \mathrm{C}$. The film deflection $(\mathrm{X})$ data were inconclusive for the dependency on the glass and pour spout temperatures for the same flow rates. 


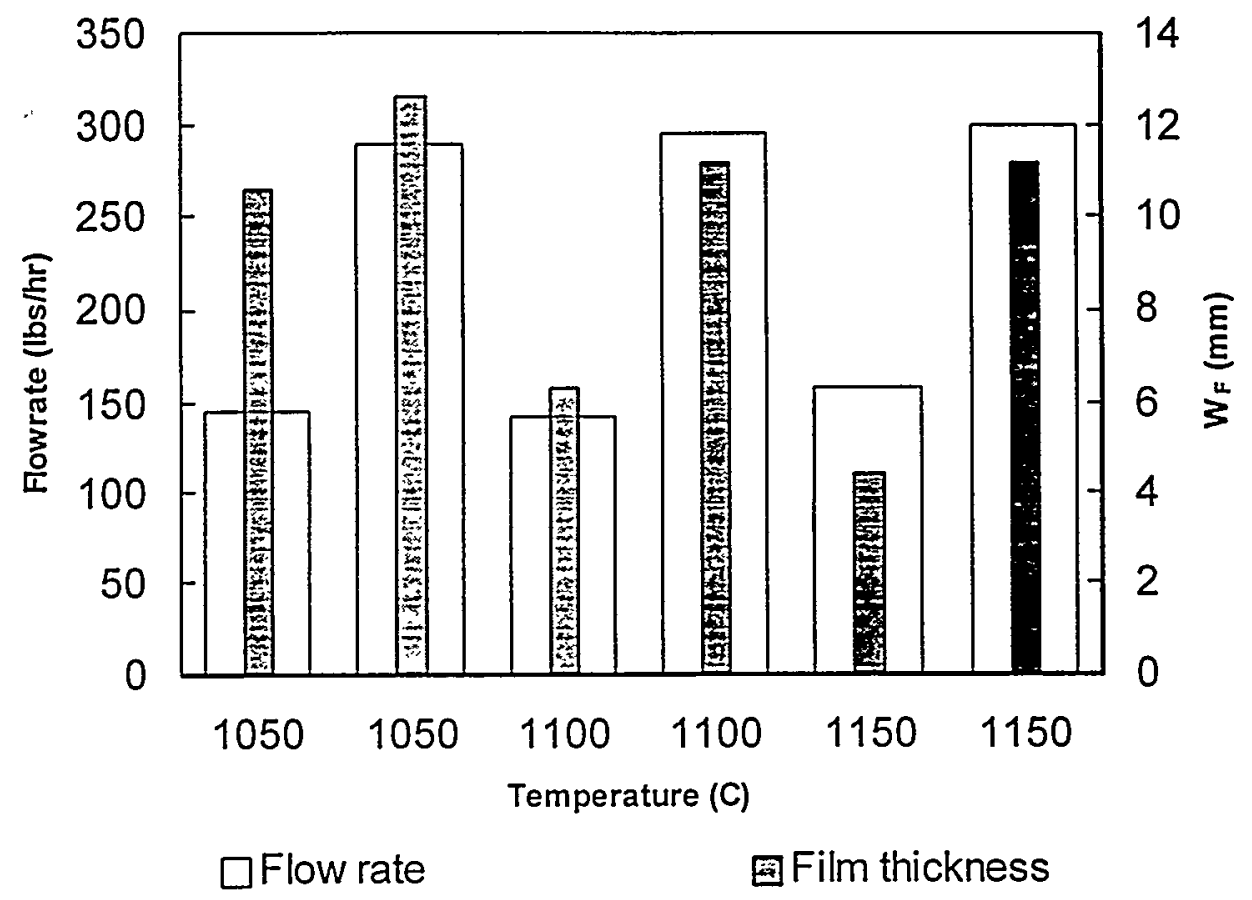

Figure 14. Variation of $W_{F}$, front glass film thickness with change of glass and pour spout temperature.

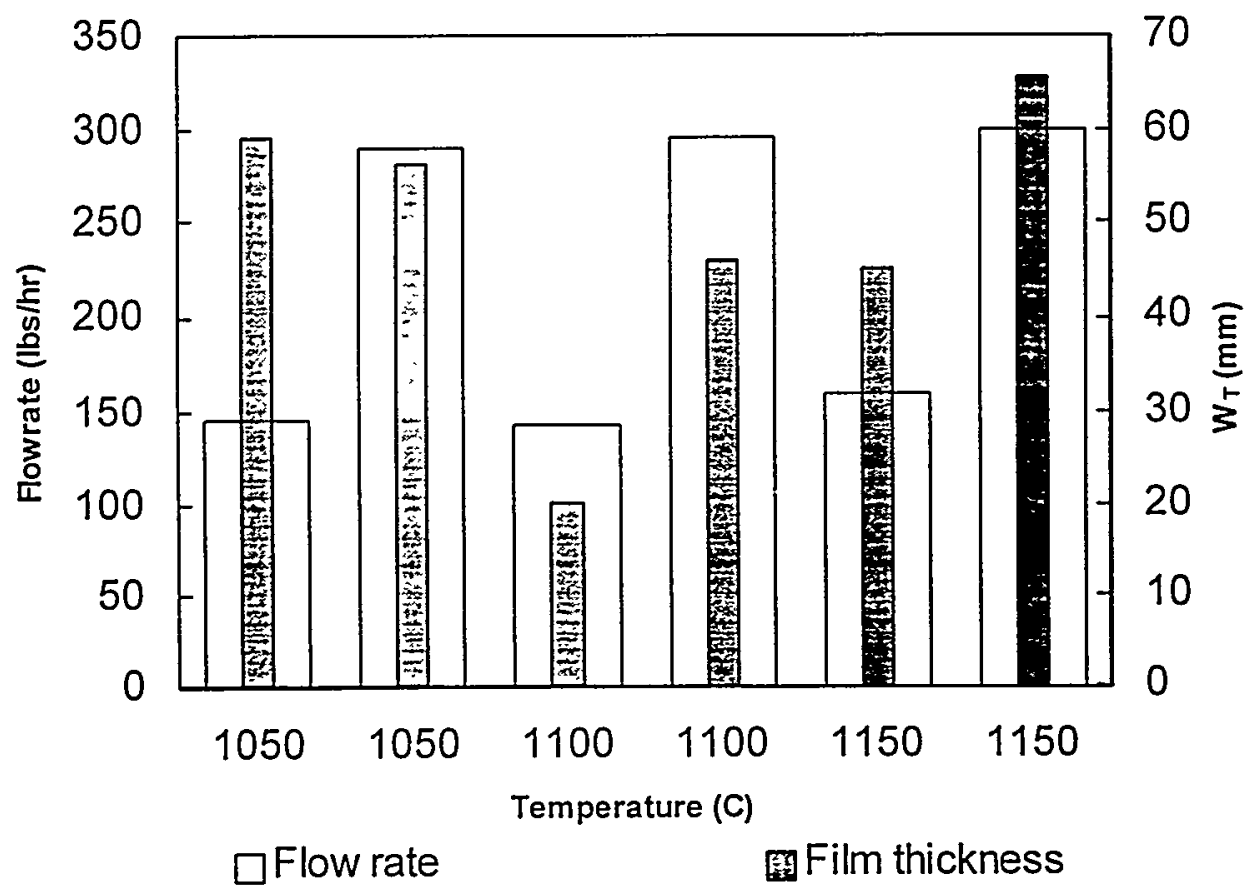

Figure 15. Variation of $W_{T}$, top glass film thickness with change of glass and pour spout temperature. 


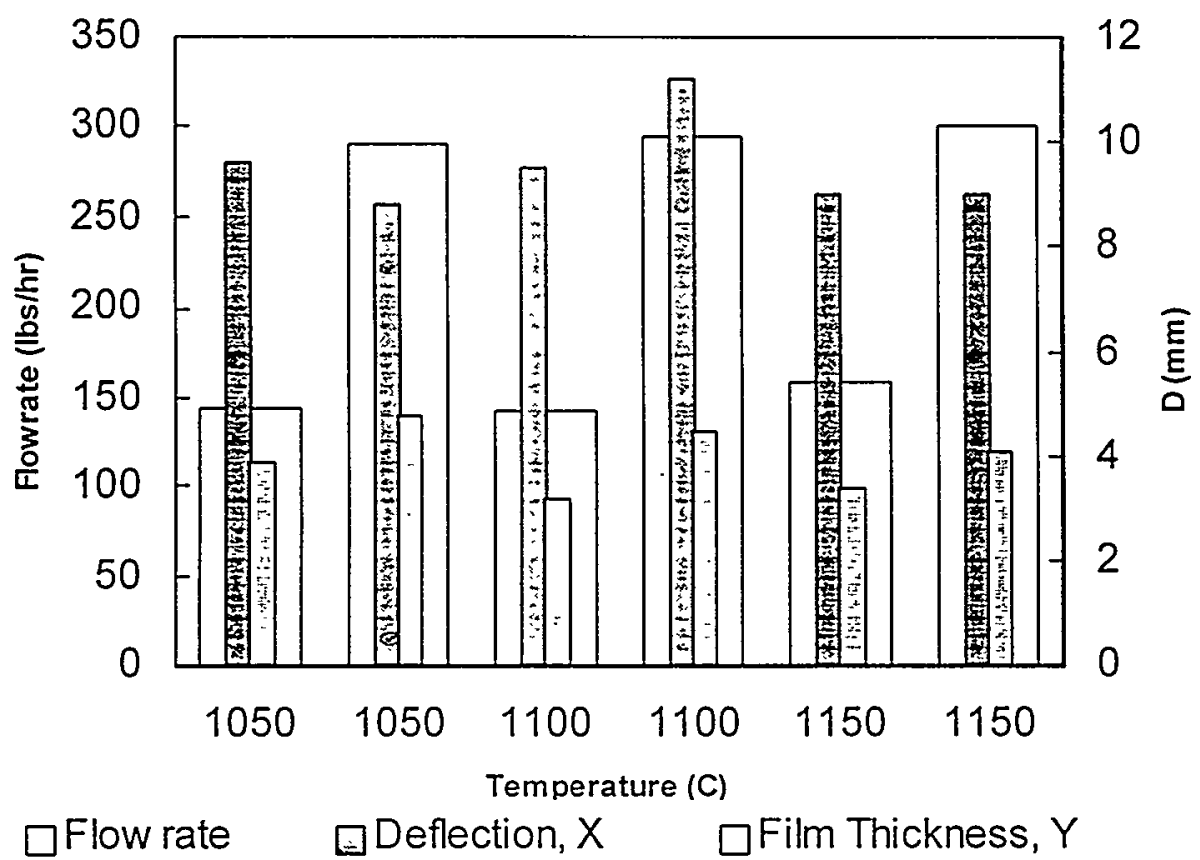

Figure 16. Variation of glass stream deflection and glass film thickness with change of glass and pour spout temperature.

\section{Variation of Pour Spout Temperature}

\section{at Fixed Glass Temperature of $1150^{\circ} \mathrm{C}(\mathrm{C} 1, \mathrm{C} 2, \mathrm{~A} 3)$}

For this case $\mathrm{W}_{\mathrm{F}}$ (front glass film thickness) and $\mathrm{W}_{\mathrm{T}}$ (top film thickness) decrease with increase in the pour spout temperature as shown in Figure 17 and Figure 18. The glass stream defection increased with increase in the pour spout temperature as shown in Figure 19. 


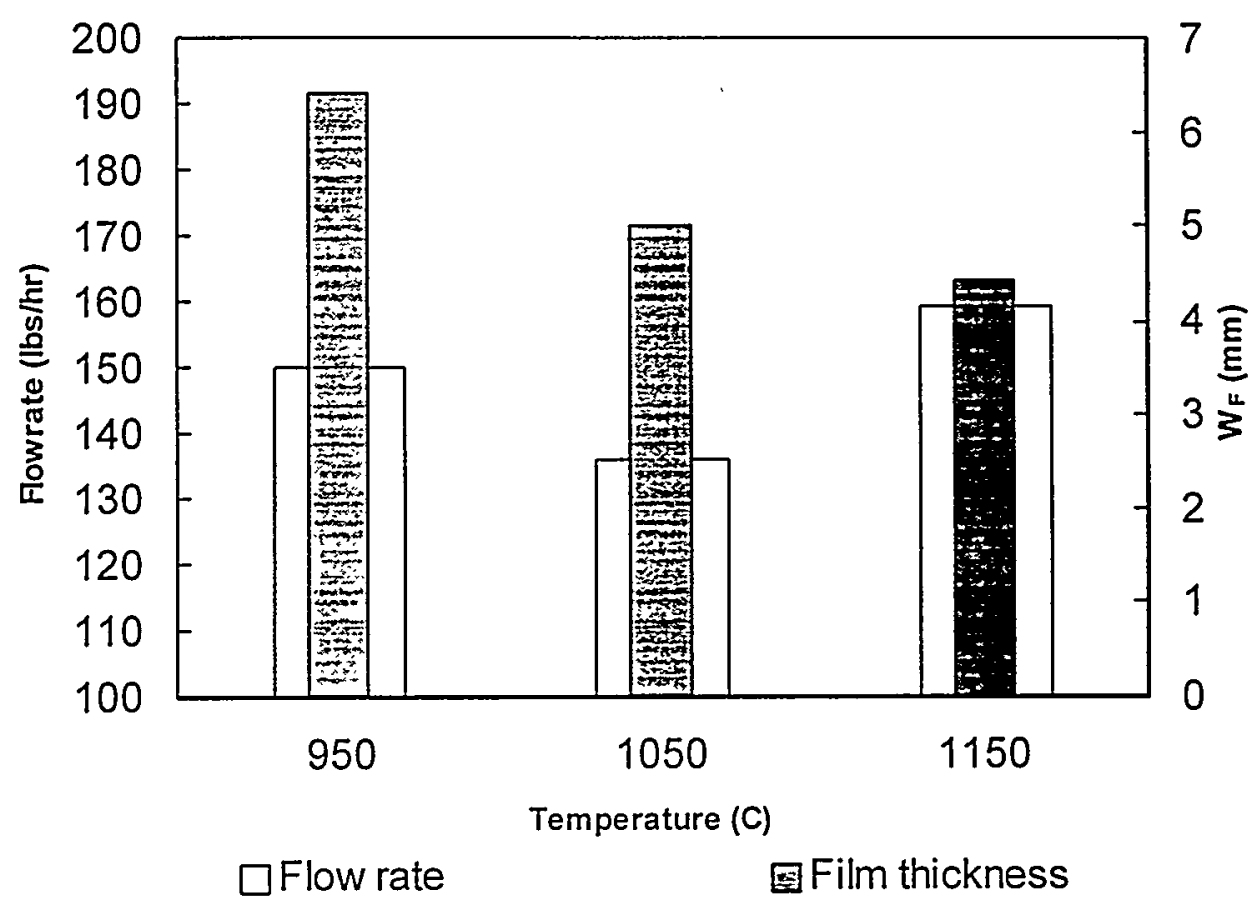

Figure 17. Variation of $W_{F}$, front glass film thickness with change of pour spout temperature at fixed glass temperature of $1150^{\circ} \mathrm{C}$.

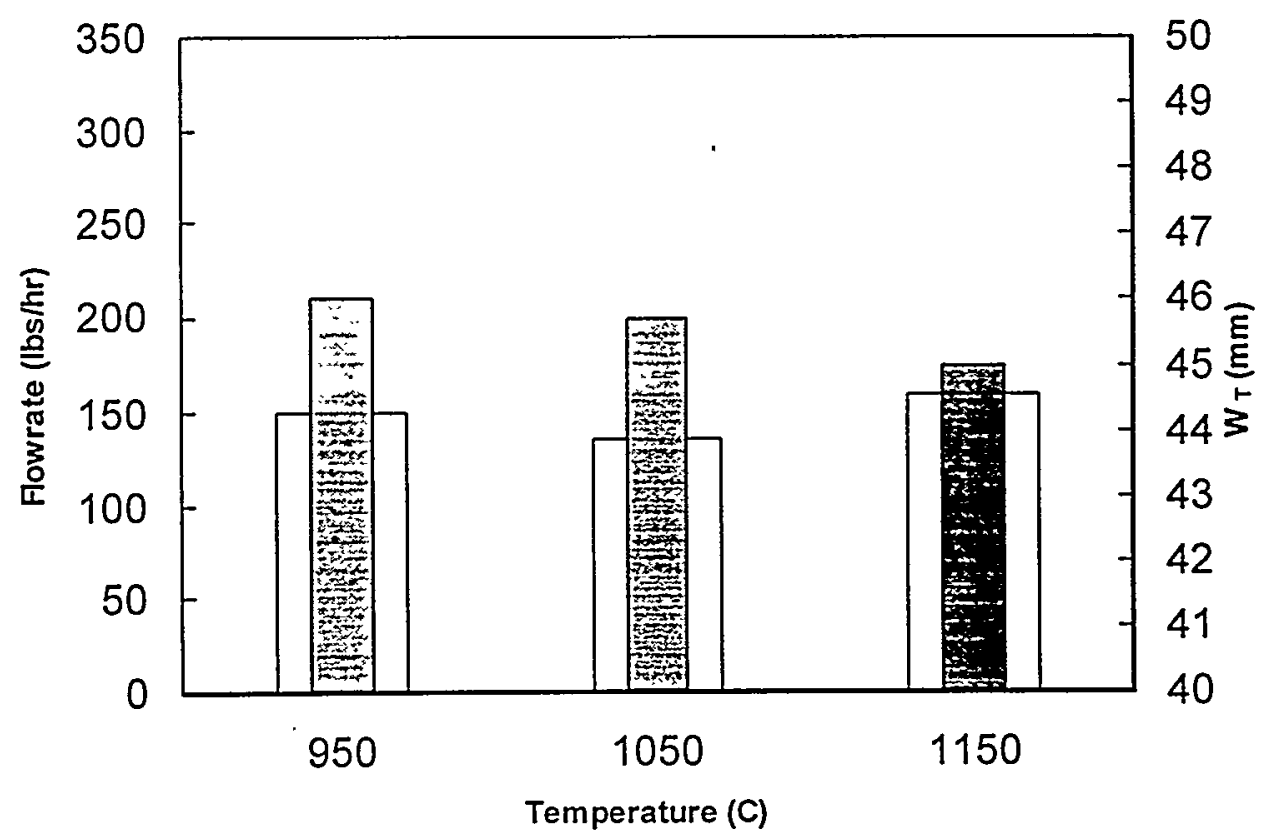

$\square$ Flow rate

圈Film thickness

Figure 18. Variation of $W_{T}$, top glass film thickness with change of pour spout temperature at fixed glass temperature of $1150^{\circ} \mathrm{C}$. 


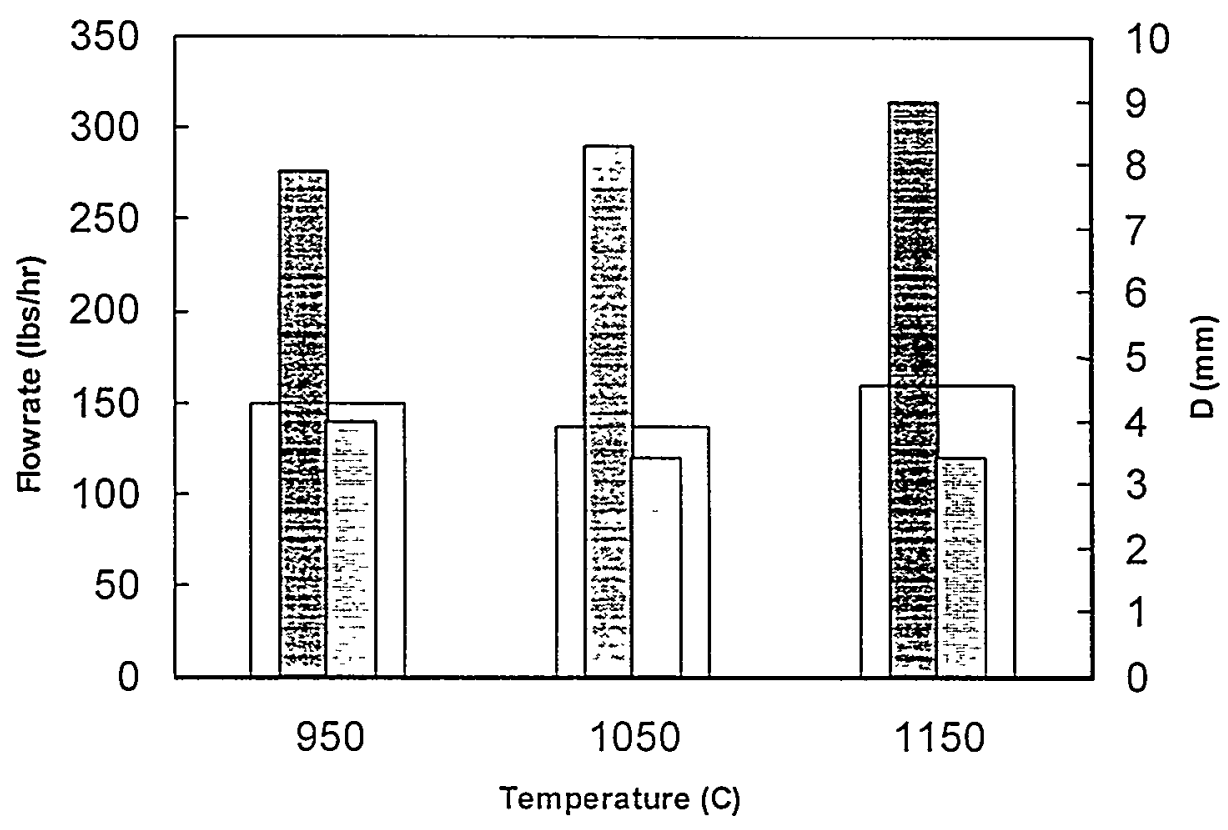

$\square$ Flow rate $\quad$ Deflection, $X \quad \square$ Film Thickness, $Y$

Figure 19. Variation of glass stream deflection and glass film thickness with change of pour spout temperature at fixed glass temperature of $1150 \mathrm{C}$.

\section{Variation of Glass Temperature (B1, D1)}

All three glass film thicknesses viz. $W_{\mathrm{F}}, W_{\mathrm{T}}$, and $\mathrm{Y}$ decreased with increase in the glass temperature with other process parameters held constant as shown in Figures 20-22. At the lower temperature of $950^{\circ} \mathrm{C}$, the glass is highly viscous, which is the cause of increased film thicknesses. 


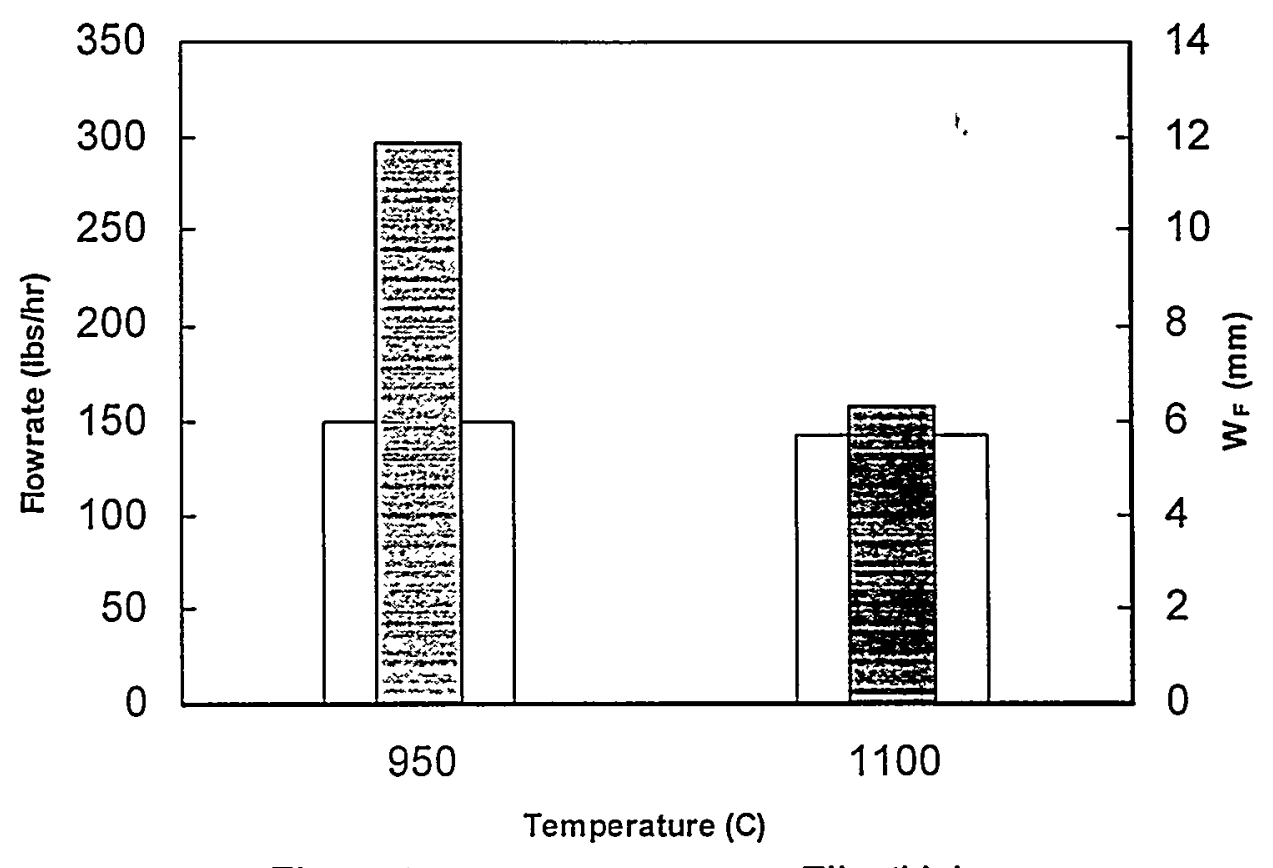

Figure 20. Variation of $W_{F}$, front glass film thickness with change in glass temperature.

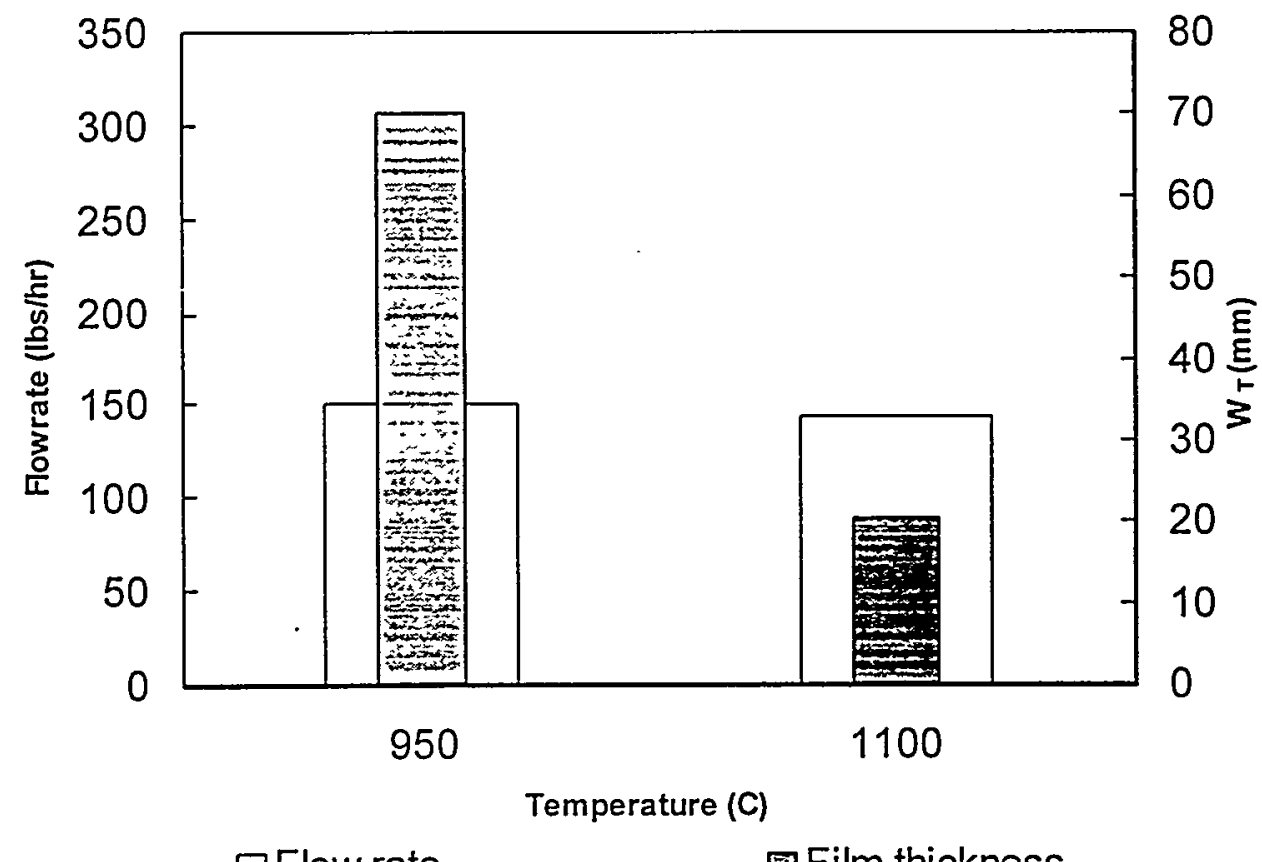

Figure 21. Variation of $W_{T}$, top glass film thickness with change in glass temperature. 


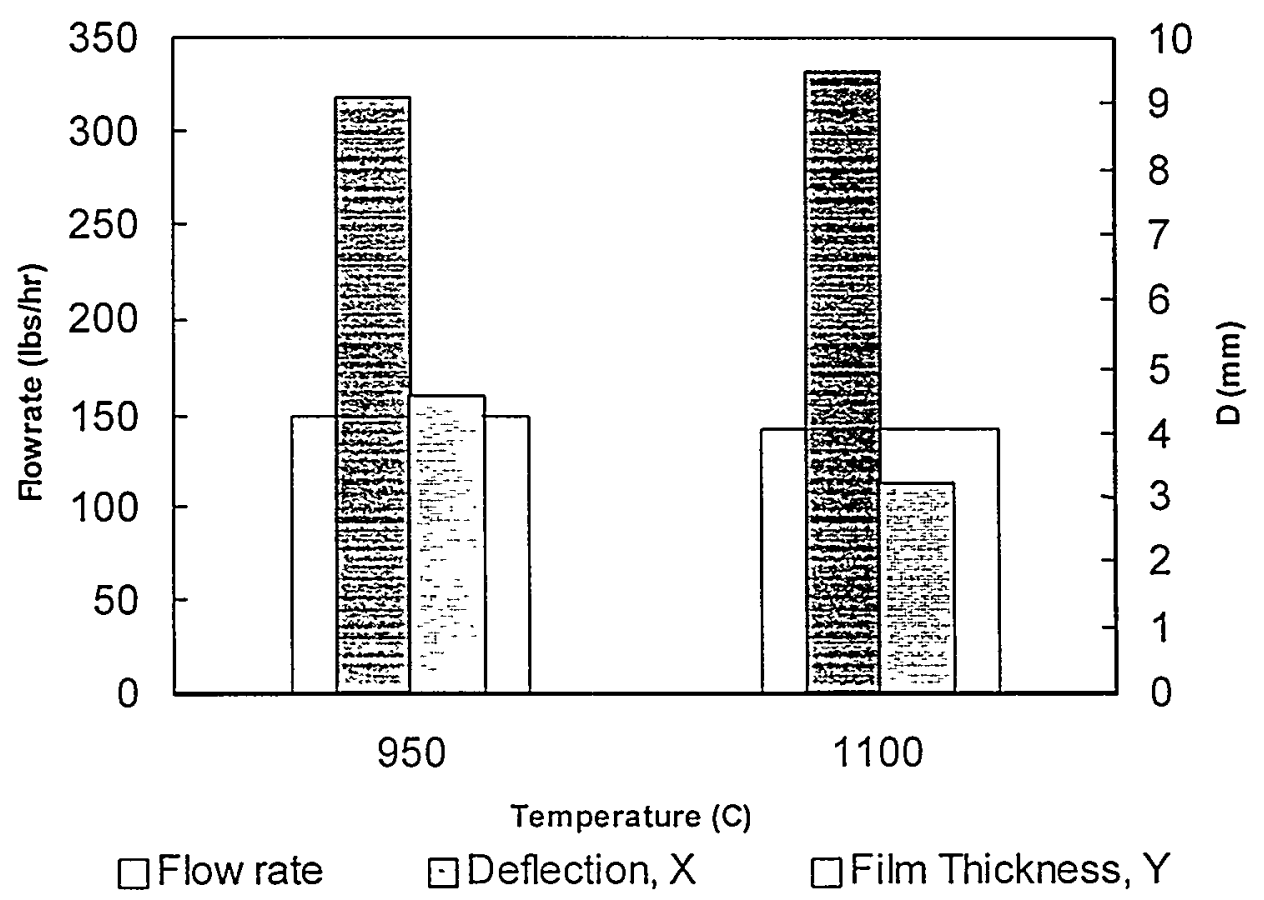

Figure 22. Variation of glass stream deflection and glass film thickness with change in glass temperature.

\section{TASK 4. OSCILLATING FLOW EXPERIMENTS}

An oscillating flow experiment was tried on the bench scale melter, but the oscillating flow conditions of the DWPF melter could not be simulated. The current setup is unable to simulate the fluctuating flow conditions as a feedback control loop system is needed to timely switch off and on the vent valve and the feed valve simultaneously. The feedback control loop is being designed and will be implemented during FY99. 


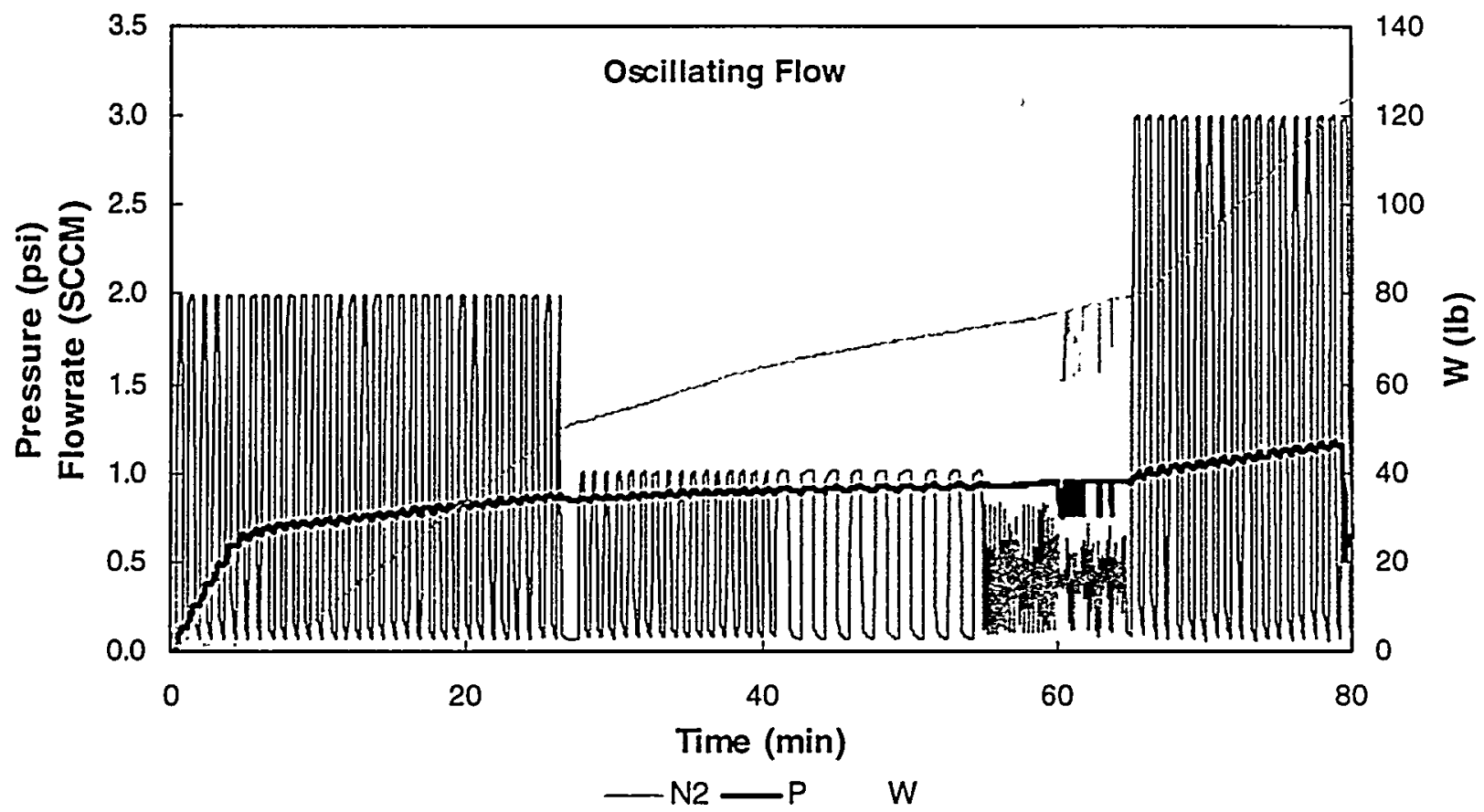

Figure 23. Test condition showing negligible glass flow fluctuations with upstream pressure variations.

\section{TASK 5. MODELING OF TRANSIENT GLASS FLOW (NOT INCLUDED IN PTP 98)}

Consider the simplified schematic of the melter shown in Figure 24. The glass is initially at ho inside the melter and in the semi-cylindrical riser section. When gas enters the melter head space at $\mathrm{q} \mathrm{cc} / \mathrm{min}$, the glass level goes down in the melter by $h_{1}$ and rises in the riser by $h_{2}$. The following analysis develops a correlation for estimating time for the glass to rise to the horizontal section and the flow rate of the glass once it begins to flow. The modeling takes into account the volume expansion of the gas as it enters the melter head space. 


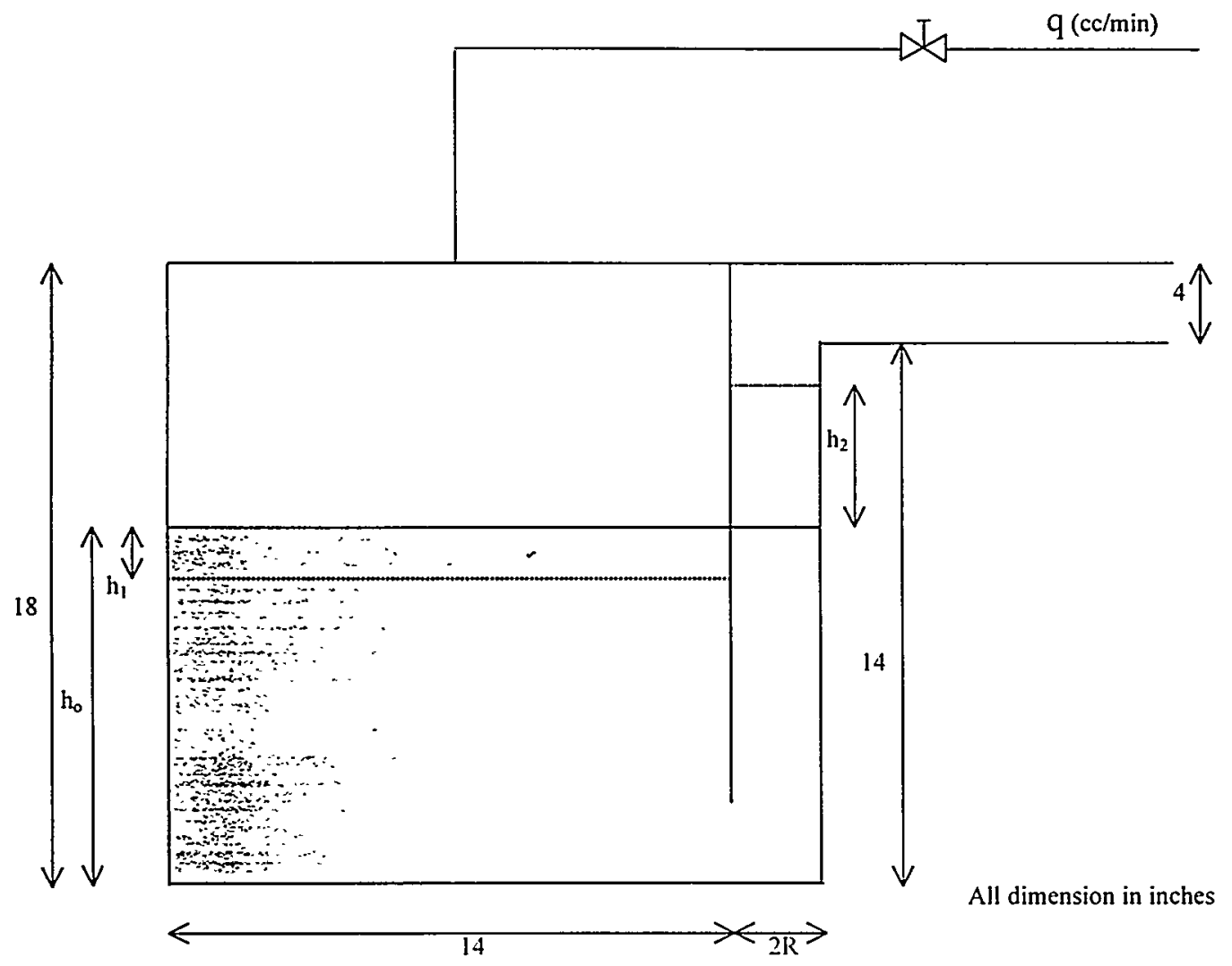

Figure 24. Schematic of melter.

\section{Stage I: (Before glass overflow)}

Initially at $t=0$, the glass is at same height $h_{0}$ in the melter and the riser. The pressure $P_{0}$ in the head space is $1 \mathrm{~atm}$, which is same as the pressure above the glass surface in the riser. At time $\mathrm{t}=0^{+}$, gas begins to flow at a rate of $\mathrm{q} \mathrm{cc} / \mathrm{min}$ in the head space above the melter causing the pressure to rise. This forces the glass height to go down in the melter and to go up in the riser section.

Let $h_{1}$ be the drop of glass height in the melter and $h_{2}$ be the increase in the glass height in the riser. From continuity:

$$
A_{1} h_{1}=A_{2} h_{2}
$$

where

$$
\begin{gathered}
A_{1}=15 \times 15, \quad \text { and } \quad A_{2}=\pi 2^{2} / 2 \\
h_{2}=122.5 h_{1}
\end{gathered}
$$

Pressure relationship: 


$$
\begin{gathered}
P_{1}=P_{2}+\rho_{g}\left(h_{1}+h_{2}\right) g \\
P_{1}=1+6.63 E-03\left(h_{1}+h_{2}\right)
\end{gathered}
$$

where $P_{2}=1$ atm (always as the system is open to the atmosphere) and $\rho_{\mathrm{g}}$ is the glass density and $\mathrm{g}$ is acceleration due to gravity.

Initial number of gas moles in the melter head space

$$
\begin{aligned}
& \mathrm{n}_{0}=\left(\mathrm{P}_{0} \mathrm{~V}_{0}\right) /\left(\mathrm{R} \mathrm{T}_{0}\right) \\
& \mathrm{P}_{0}=1 \mathrm{~atm} ., \mathrm{V}_{0}=15 \times 15 \times\left(18-\mathrm{h}_{0}\right) \times 2.54^{3} \mathrm{~cm}^{3}, \mathrm{~T}_{0}=1273 \mathrm{~K}\left(1000^{\circ} \mathrm{C}\right) \\
& \mathrm{R}=82.057 \mathrm{~atm} \mathrm{~cm}^{3} /(\mathrm{g}-\text { moles } \mathrm{K})
\end{aligned}
$$

Calculate $\mathrm{n}_{0}$

$$
n_{0}=2.896\left(18-h_{0}\right) / R \quad g-\text { moles }
$$

A steady flow rate of gas is assumed. What are the conditions in the furnace after $t$ minutes?

Number of moles which have entered the melter head space in $t$ min. (from gas law)

$$
n_{e}=P_{1} \times q t /(R 298)
$$

This is because the gas is at room temperature $\left(298^{\circ} \mathrm{K}\right)$ before entering the melter and the pressure in the line is the same as the pressure in the head space, because of continuity and assuming minimal head loss for the gas in the $1 / 4$ " feeder line.

The new pressure in the melter space can be calculated using the gas law:

$$
\begin{gathered}
\mathrm{P}_{1}=\left(\mathrm{n}_{0}+\mathrm{n}_{\mathrm{e}}\right) \mathrm{R} \times 1273 /\left(\left(18-\mathrm{h}_{0}-\mathrm{h}_{1}\right) \times 15 \times 15 \times 2.54^{3}\right) \\
\mathrm{P}_{1}=0.34526 \frac{\left[\frac{\mathrm{P}_{1} \mathrm{qt}}{298.0}+2.896\left(18-\mathrm{h}_{0}\right)\right]}{\left[18-\mathrm{h}_{0}-\mathrm{h}_{1}\right]}
\end{gathered}
$$

where $P_{1}$ is in atm., $h_{0}$ and $h_{1}$ are in inches, $q$ is in cc/min, and $t$ is in min.

Consider eq. 3, eq. 5 , and eq. 10.

Knowns: $h_{0}, P_{2}, q, t, g$, and $\rho_{g}$

Unknowns: $\mathrm{P}_{1}{ }^{*}, \mathrm{~h}_{1}{ }^{*}$ and $\mathrm{h}_{2}{ }^{*}$

There are 3 equations ( 1 nonlinear) and 3 unknowns. The system can be solved. 


\section{Calculations:}

\begin{tabular}{|c|c|c|c|c|}
\hline \multicolumn{2}{|c|}{ Input Block } & \multirow[b]{2}{*}{$(\mathrm{cc} / \mathrm{min})$} & & \\
\hline$q$ & 100 & & & \\
\hline ho & 10 & (in) & & \\
\hline \multicolumn{2}{|c|}{ Output Block } & & & $\mid$ \\
\hline $\mathrm{h} 2^{*}=$ & 4 & \multicolumn{3}{|c|}{ when glass begins to overflow } \\
\hline $\mathrm{hI}^{*}=$ & 0.0356 & \multicolumn{2}{|c|}{ glass overflow } & \\
\hline $\mathrm{PI}^{*}=$ & 1.0268 & atm & 0.3935 & psi gage \\
\hline$t^{*}=$ & 1.50 & $\min$ & & \\
\hline
\end{tabular}

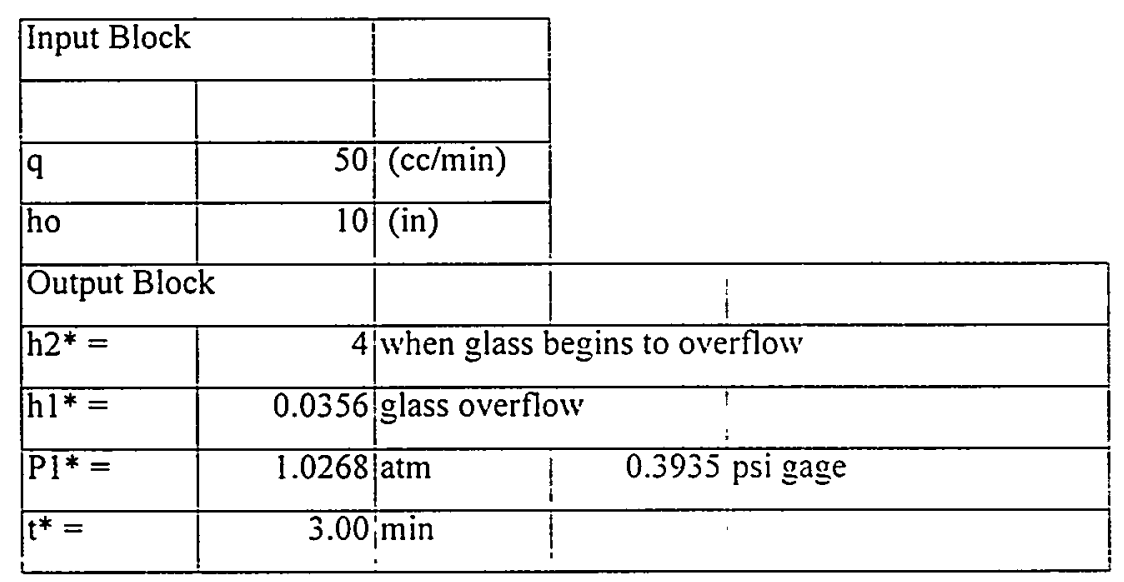

\begin{tabular}{|c|c|c|c|}
\hline Input $\mathrm{E}$ & & & \\
\hline $\mathrm{q}$ & 50 & (cc/min) & \\
\hline ho & 6 & (in) & \\
\hline Output & & & \\
\hline $\mathrm{h} 2^{*}=$ & 8 & when glas & is to overflow \\
\hline $\mathrm{hl^{* } =}$ & 0.0711 & glass over & \\
\hline$\overline{\mathrm{P}} 1^{*}=$ & 1.0535 & atm & 0.7870 gage \\
\hline$t^{*}=$ & 9.32 & $\min$ & \\
\hline
\end{tabular}




\begin{tabular}{|c|c|c|c|c|}
\hline \multicolumn{2}{|c|}{ Input Block } & \multirow[b]{2}{*}{$(\mathrm{cc} / \mathrm{min})$} & & \\
\hline$q$ & 100 & & & \\
\hline ho & 6 & (in) & & \\
\hline \multicolumn{2}{|c|}{ Output Block } & & & \\
\hline $\mathrm{h} 2^{*}=$ & $\overline{8}$ & \multicolumn{3}{|c|}{ when glass begins to overflow } \\
\hline $\mathrm{h}^{*}=$ & 0.0711 & \multicolumn{2}{|c|}{ glass overflow } & \\
\hline $\mathrm{P} 1^{*}=$ & 1.0535 & atm & 0.7870 & gage \\
\hline$t^{*}=$ & 4.66 & $\min$ & & \\
\hline
\end{tabular}

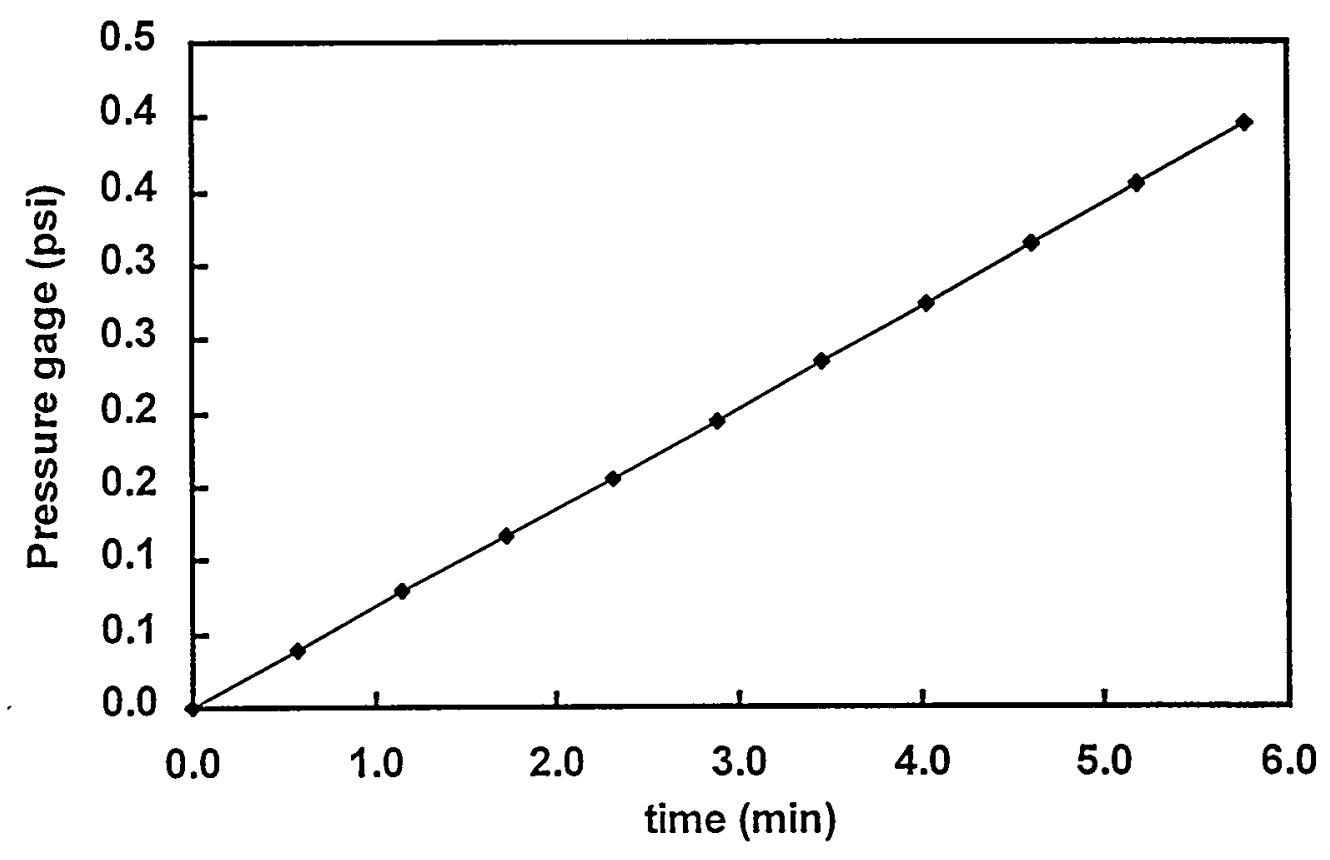

Figure 25. Increase in melter pressure for a gas flow rate of $50 \mathrm{cc} / \mathrm{min}$ and an initial glass height of $8^{\prime \prime}$. It will take $5.76 \mathrm{~min}$. for the glass to rise to the top of the riser. 
When the glass begins to flow and the correlation that is satisfied is:

$$
\mathrm{h}_{0}+\mathrm{h}_{2}{ }^{*}=14
$$

or,

$$
\mathrm{h}_{2}{ }^{*}=14-\mathrm{h}_{0}
$$

Now $\mathrm{h}_{2}{ }^{*}$ is known and hence $\mathrm{h}_{1}{ }^{*}, \mathrm{P}_{1}{ }^{*}$ and $\mathrm{t}^{*}$ can be readily calculated to find the time required for glass overflow for a given gas flow rate.

\section{Stage II (Glass begins to overflow)}

$$
h_{2}=14-h_{0}
$$

Once this condition is reached, there is no further increase in height in h2. This is idealized condition. The height of the glass thickness in the horizontal pour spout is ignored.

The pressure equation from before

$$
P_{1}=P_{2}+\rho_{g}\left(h_{1}+h_{2}\right) g
$$

Using eq. 12 , modifies to

$$
P_{1}=1+6.63 E-03\left(h_{1}+14-h_{0}\right)
$$

Eq. 10 remains same as before

$$
\mathrm{P}_{1}=0.34526 \frac{\left[\frac{\mathrm{P}_{1} \mathrm{qt}}{298.0}+2.896\left(18-\mathrm{h}_{0}\right)\right]}{\left[18-\mathrm{h}_{0}-\mathrm{h}_{1}\right]}
$$

Eq. 10 and Eq. 13 can now be solved for the two unknowns $h_{1}$ and $P_{1}$. The modeling results compare favorably with the experiments.

Also, using Eq. 10 and Eq. 13 and differentiating once with time ' $t$ ', it can be shown that

$$
\frac{\mathrm{dh}}{\mathrm{dt}}=\frac{\mathrm{q}}{102.89} \frac{\left[1+6.63 \mathrm{E}-03\left(\mathrm{~h}_{1}+\left(14-\mathrm{h}_{0}\right)\right]\right.}{\left[-0.013 \mathrm{~h}_{1}-0.973\right]}
$$

From Eq. 14 the glass flow rate W (lb/hr) can be calculated as

$$
\dot{\mathrm{W}}=\rho_{g} \mathrm{~A}_{1} \frac{\mathrm{dh}}{\mathrm{dt}}
$$

where $\rho_{g}$ is the density of glass $\left(\mathrm{lb} / \mathrm{ft}^{3}\right)$. 


\subsection{DISCUSSION OF FY98 ACTIVITIES}

\section{LESSONS LEARNED}

Inexperience of the furnace vendor caused unforeseen problems for the project, although FIUHCET was able to catch up toward the end of the fiscal year. Failure to meet the design requirements by the vendor along with the steep learning curve caused delays toward the end.

\section{PRELIMINARY CONCLUSIONS}

The FIU-HCET melter is unique in the sense that it provides 4 views (1 top, 1 front, and 2 side views) for glass flow over the knife edge. Initial testing shows that under steady glass flow rates there exists a critical flow rate below which the "wicking" phenomenon is observed. "Wicking" is defined as the departure of the glass stream from a normal vertical trajectory previously observed in DWPF under startup/shutdown and oscillatory flow conditions. For the bench-scale melter, wicking is observed at flow rates of under $40 \mathrm{lb} / \mathrm{hr}$.

\section{BRIEF DESCRIPTION OF DATA}

Baseline runs provided the following general insight into glass flowing over a knife edge:

Glass film thickness increases with increase in flow rate.

For the range of experimental conditions for the baseline runs, temperature profiles in the pour spout had insignificant effect on the deflection of the glass stream (X).

More viscous glass resulted in increased film thickness. 


\subsection{PLANNED ACTIVITIES FOR FY99}

FIU-HCET will expand parametric investigations of the glass pouring process during FY99 to gain a fundamental understanding of the problems encountered in pouring glass and to develop possible solutions. The overall objective is a continuation of tasks established in FY98. The tasks listed below will determine the effect of the following operating conditions on the glass pouring behavior:

- Crud deposits on the back side of the knife edge

- Eroded pour spout knife edge

- Sleeve/knife edge gap

- Glass chemistry.

\section{BENEFITS}

It is expected that the results of this subtask may provide experimental data to confirm the model calculations obtained by the Savannah River Site technical staff. Additionally, the data can be utilized by the vitrification technology implementation management to modify future melter or modify current melter operational conditions. If successful, this program will lead to major cost savings for the U.S. Department of Energy in the form of more effective production and diminished downtime for cleaning the pour spouts.

\section{FY 99 PROJECT TASKS}

\section{Task 1. Installation of an additional heat zone}

A heat zone will be added to the existing pour spout to control the temperature of the knife edge. Also, to minimize the end heat losses, a reflective shield will be installed at the bottom of the pour spout.

\section{Task 2. Effect of crud deposits on the back side of the knife edge}

The effect of crud deposits on the back side of the knife edge will be simulated with a pour spout knife edge model having a 0 degree cutback angle (horizontal). This will be simulated by installing an insert that fits in the annular cavity behind the first knife edge (eroded knife edge 1). The knife edge will be rounded to a $1 / 16$-inch radius. The objective of this test is to determine at what flow rates glass will follow this horizontal plane or depart vertically from the knife edge.

\section{Task 3. Effect of protypical pour spout geometry/surface condition}

The effect of an eroded/corroded pour spout knife edge will be tested at low, nominal, and high fiow rates. Three types of erosion profiles will be tested. 
Task 3a. Eroded knife edge 2 (EKE 2)

For task $3 \mathrm{a}$, the original knife edge will be cut azimuthally so that the knife edge will have a scalloped shape (Eroded Knife Edge, EKE 2) when seen in the horizontal direction.

Task 3b. Eroded Knife Edge 3 (EKE 3)

For task $3 \mathrm{~b}$, the knife edge will be cut back at a reverse angle of $3^{0}$ starting from the middle of the pour spout ( 4.5 inches from the top) to represent radial. Reverse angle means that the pour spout surface will be sloped toward the melter. Both steady and oscillatory flows will be used. The steady flows will be the initial flow of the transient. The oscillatory flows will have an average flow equal to the initial flow and have a period of between 5-10 seconds.

\section{Task 3c. Eroded Knife Edge + (EKE 4)}

For task $3 c$, a narrow channel, one-inch wide, will be cut on the surface of the pour spout extending from the middle of the pour spout to the knife edge with a maximum depth of 0.25 inch at the Eroded Knife Edge 4. The same pour spout blank can be used for EKE 3 and EKE 4 by starting with EKE 4 and then machining the reverse angle $360^{\circ}$ for EKE 3 . Both steady and oscillatory flows will be used. The steady flows will be the initial flow of the transient. The oscillatory flows will have an average flow equal to the initial flow and have a period of between 5-10 seconds.

\section{TASK 4. EFFECT OF GLASS CHEMISTRY}

The effect of a different glass chemistry which leads to different surface tension and viscosity properties than the present glass simulant being used will be tested. At this time, the specific glass chemistry has not been determined so that the following tests are for planning purposes only. The nominal pour spout geometry will be used as well as the type of eroded knife edge determined by previous tests to be most conducive to wicking. The effect on the contact angle and stream deflection will be tested at steady and transient flows. 


\subsection{REFERENCES}

ANSI/ISO/ASQC Q9001-1994, Quality Systems-Model for Quality Assurance in Design, Development, Production, Installation, and Servicing.

ANSI/ASQ/SQC E4-1994, Specifications and Guidelines for Quality Systems for Environmental Data Collection and Environmental Technology Programs.

Bansal, N.P., and Doremus, R.H., 1986, Handbook of Glass Properties, Academic Press, New York.

Begley, E.R., 1970, Guide to Refractory and Glass Reactions, Cahners Publishing Company, Boston.

Ebadian, M.A. and Dong, Z., 1996, Melting, Solidification, Remelting, and Separation of Glass and Metals-Project Technical Plan, Hemispheric Center for Environmental Technology, Miami.

McMillan, P.W., 1979, Glass-Ceramics, Academic Press, London.

Phillips, C.J., 1960, Glass: Its Industrial Applications, Rheinhold Publishing Company, New York.

Schuller, F., 1970, Glassforming, Chilton Book Company, Philadelphia.

U.S. Department of Energy, DOE Order 5700.6C, Quality Assurance.

Vitrification Technologies for Treatment of Hazardous and Radioactive Waste, US-EPA/625/R92/002.

Vogei, W., 1985, "Chemistry of Glass," American Chemical Society, Columbus, OH. 


\section{APPENDIX A}

\section{FURNACE DELIVERY PHOTOGRAPHS}




\section{FURNACE DELIVERY PHOTOGRAPHS}
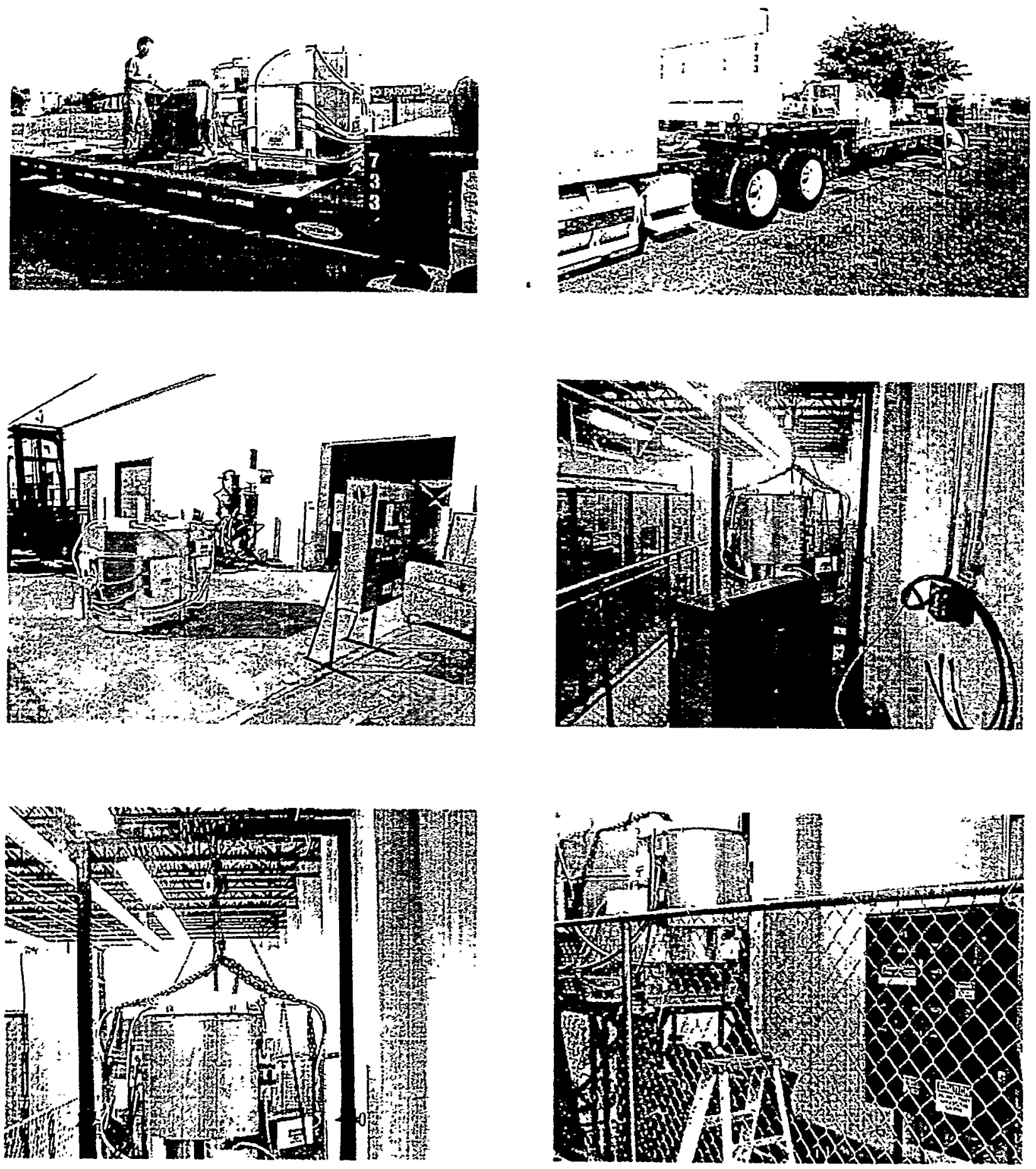


\section{APPENDIX B}

\section{HEATING ELEMENT BREAKAGE}


May 22, 1998 (Zone 3 shrinkage)

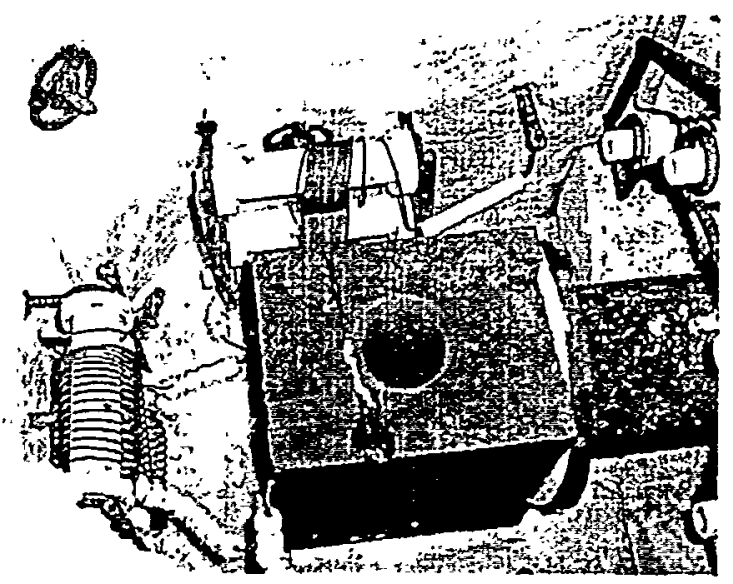

June 18, 1998 (Zone 3 burnout)
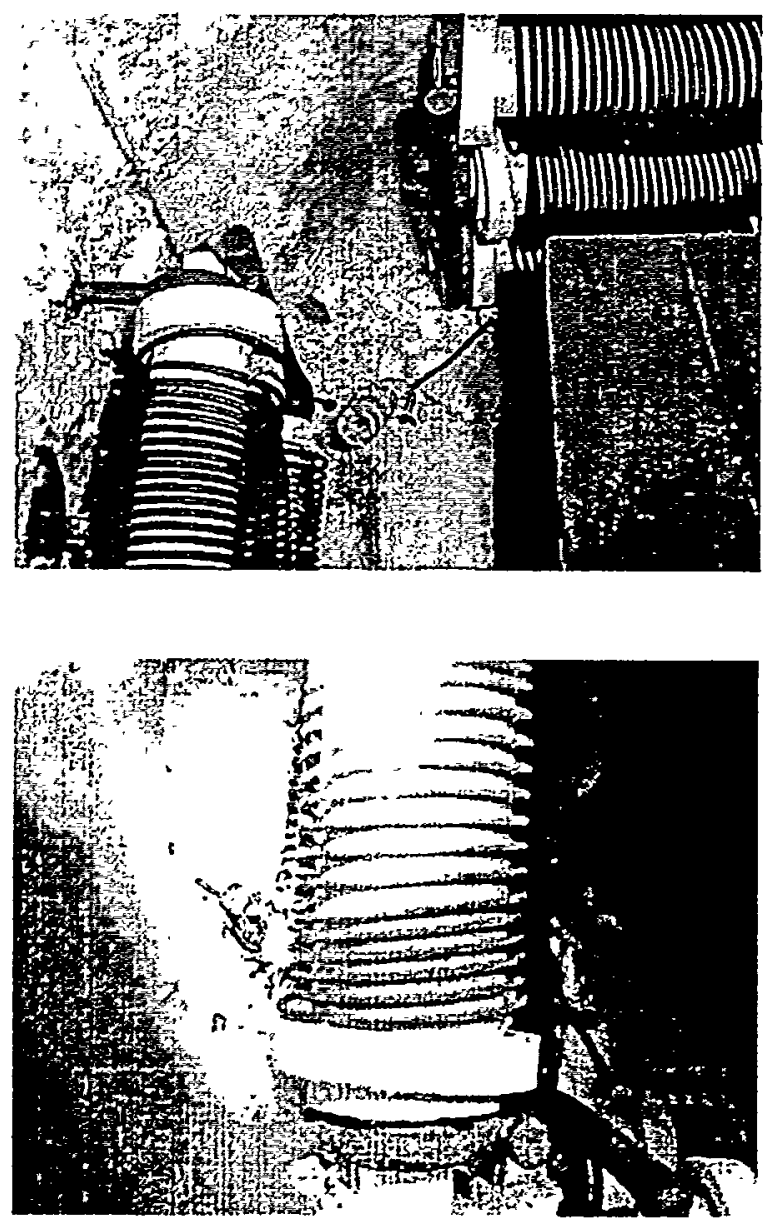
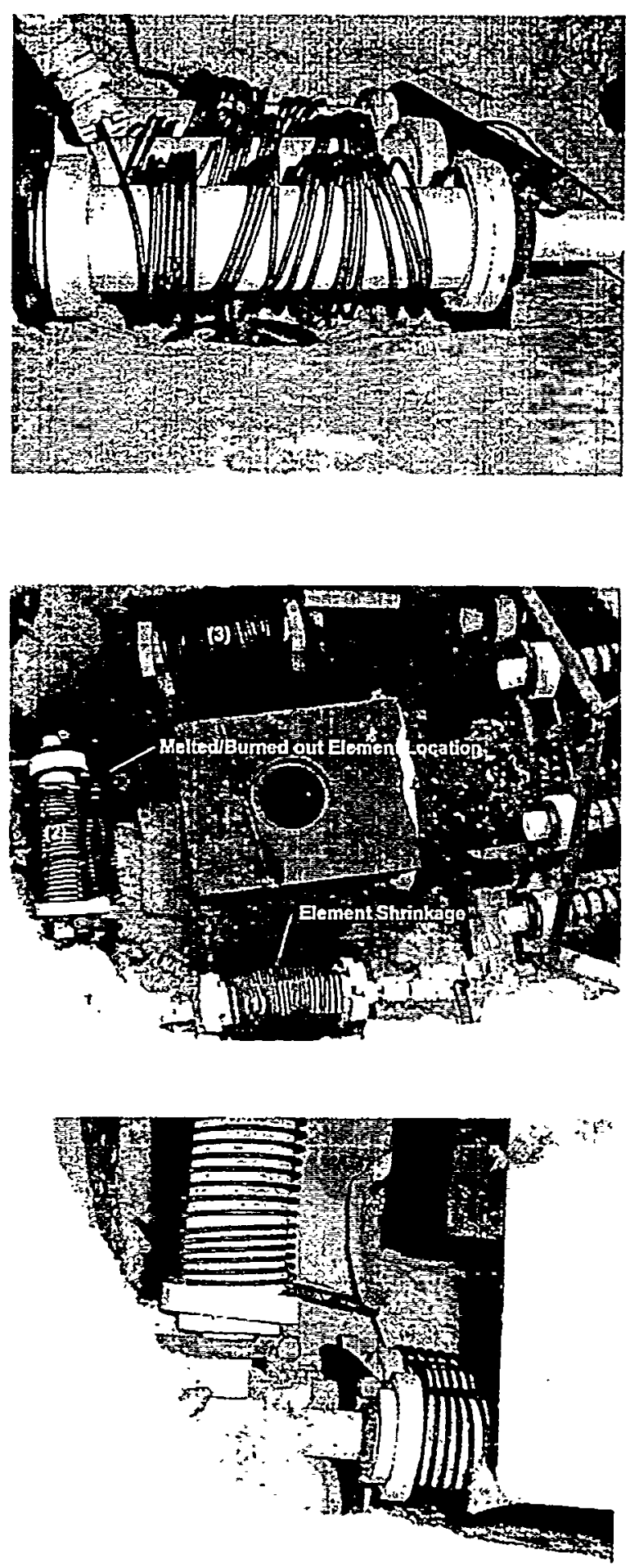
July 10, 1998 (Zone 3 shrinkage)
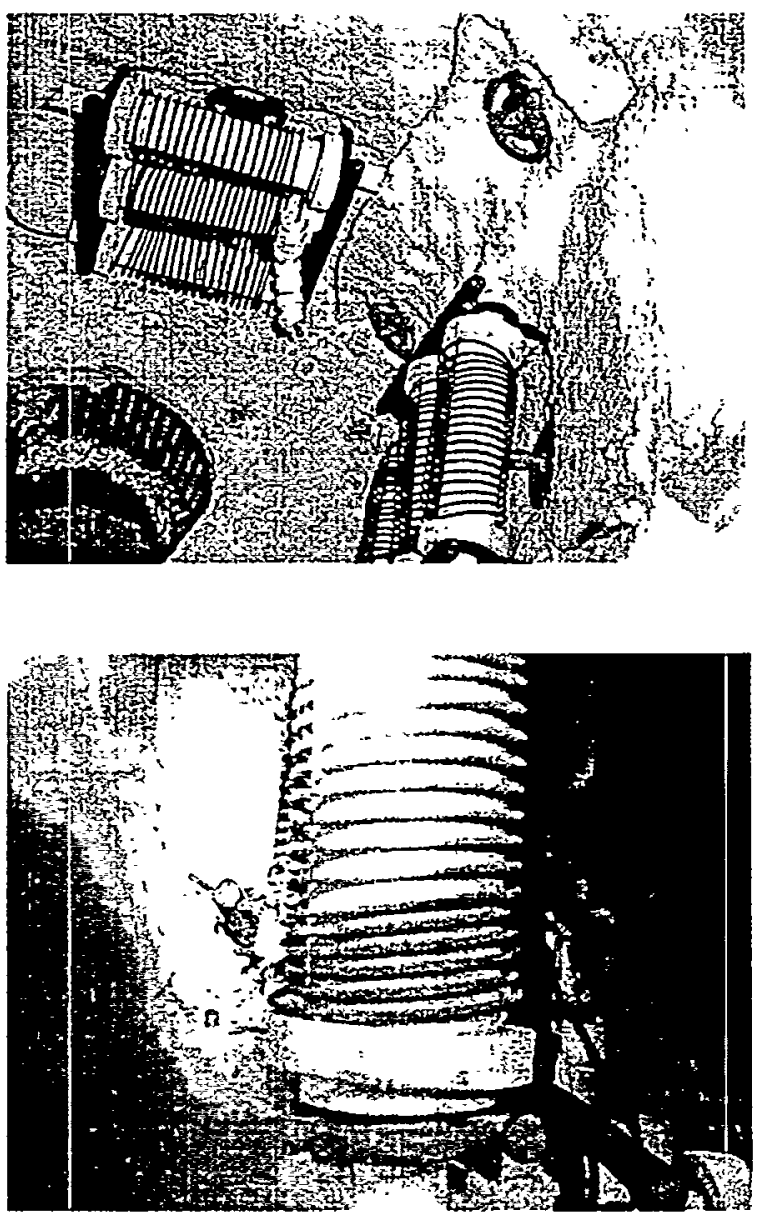

July 22, 1998 (plugging)

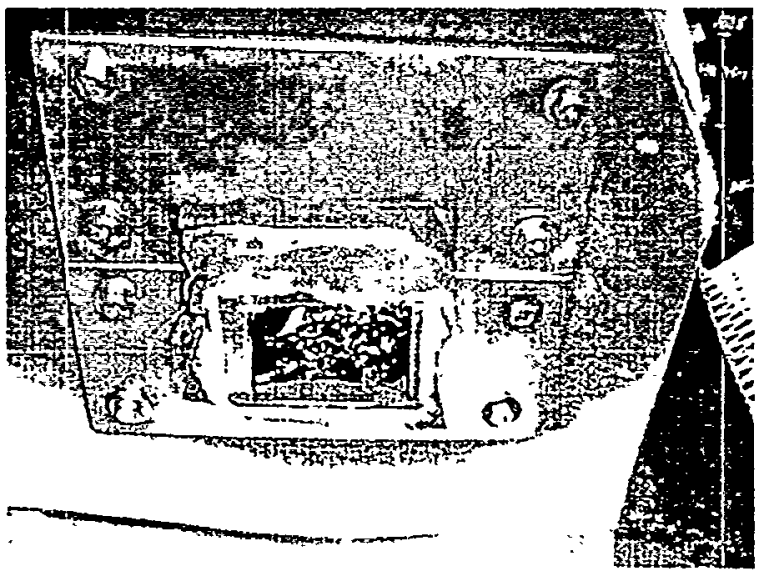

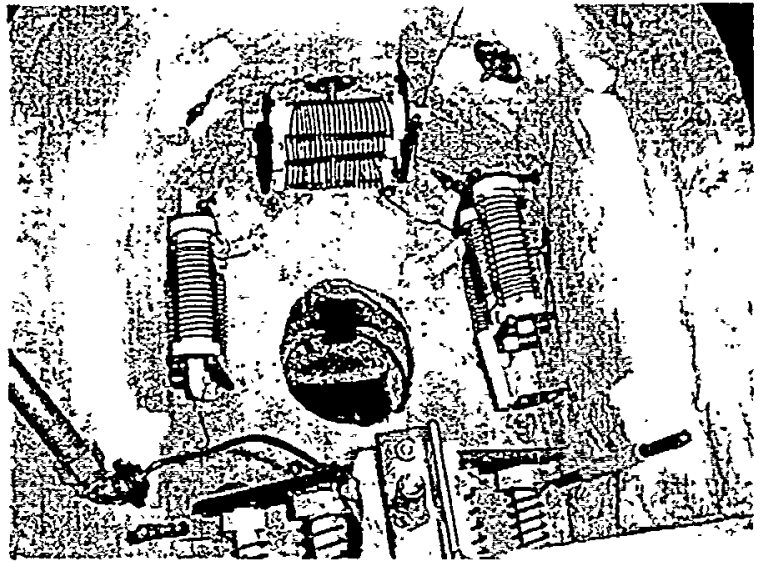

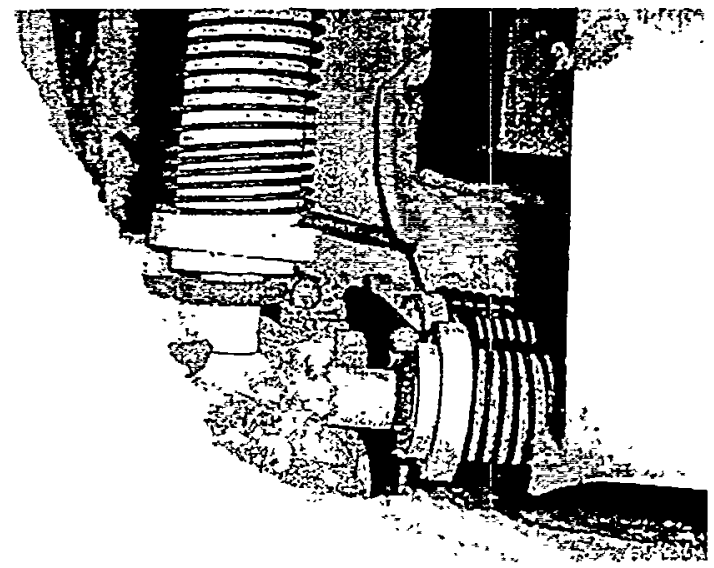


July 22, 1998 (plugging)
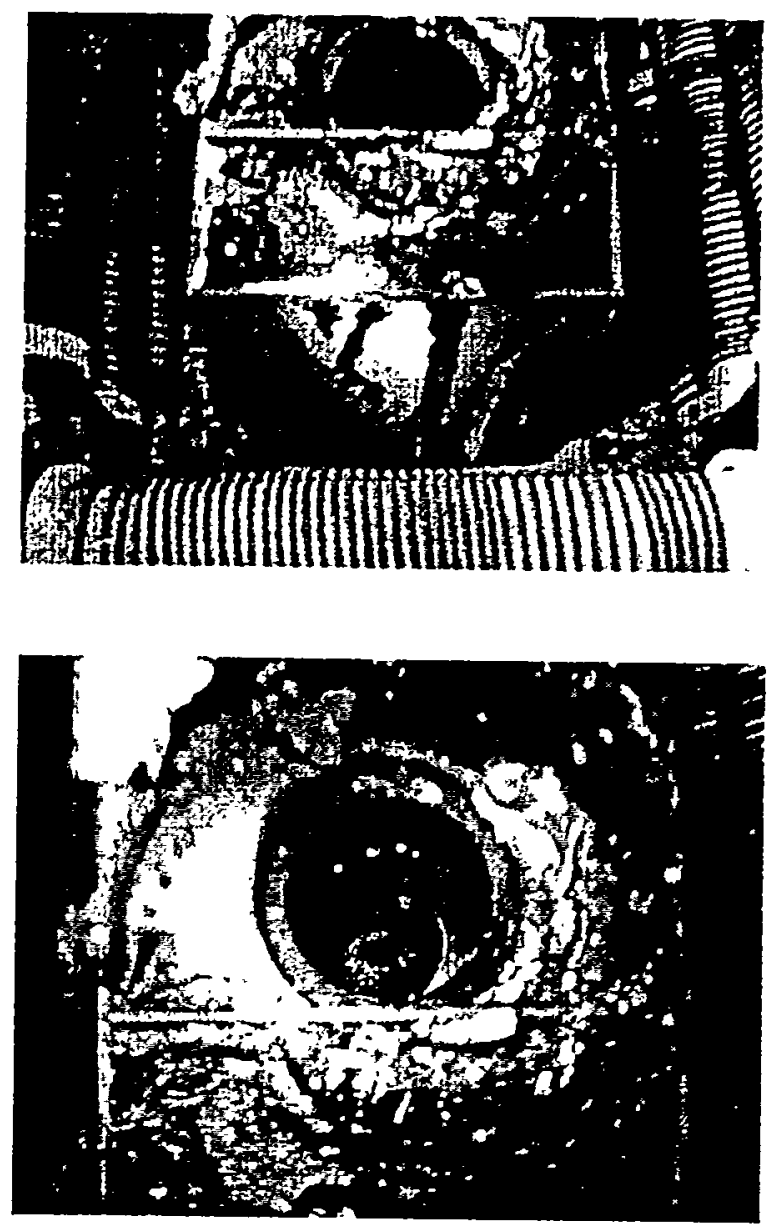

July 22, 1998 (Zone I shrinkage)

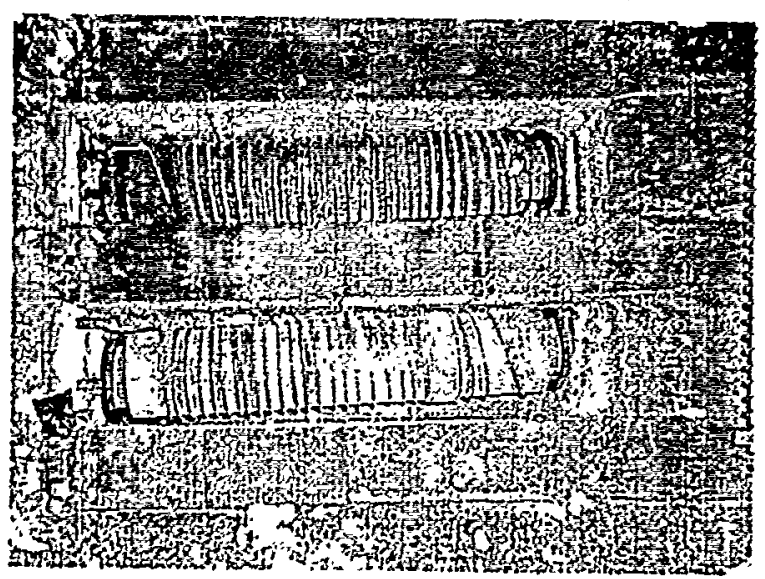

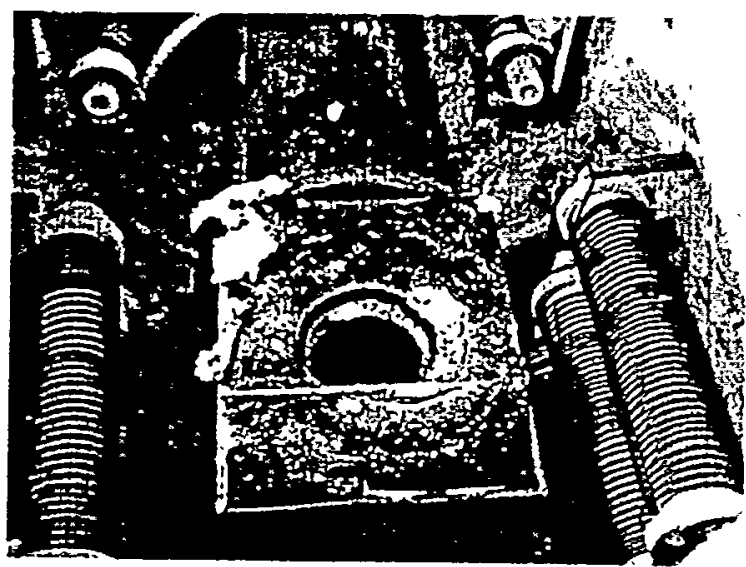
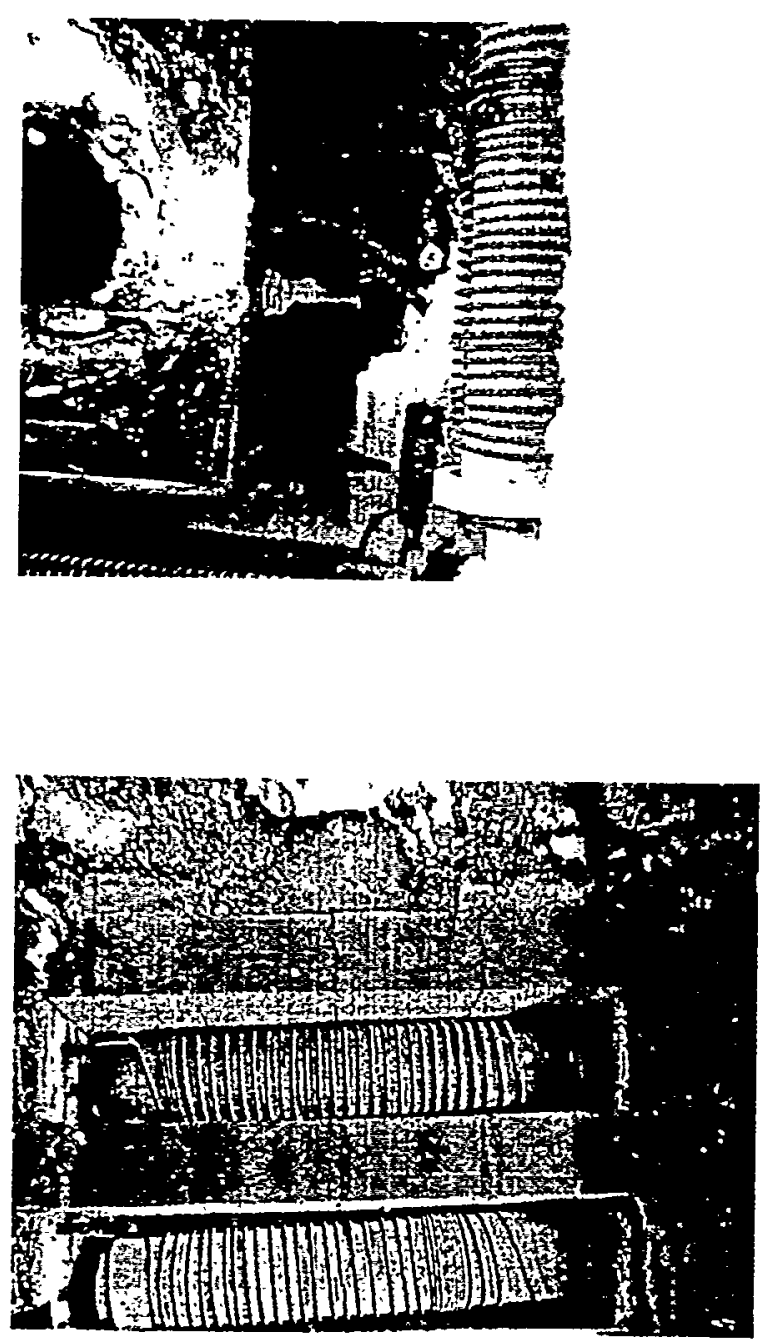


\section{Element Burnout Zone 4 (September 10, 1998)}
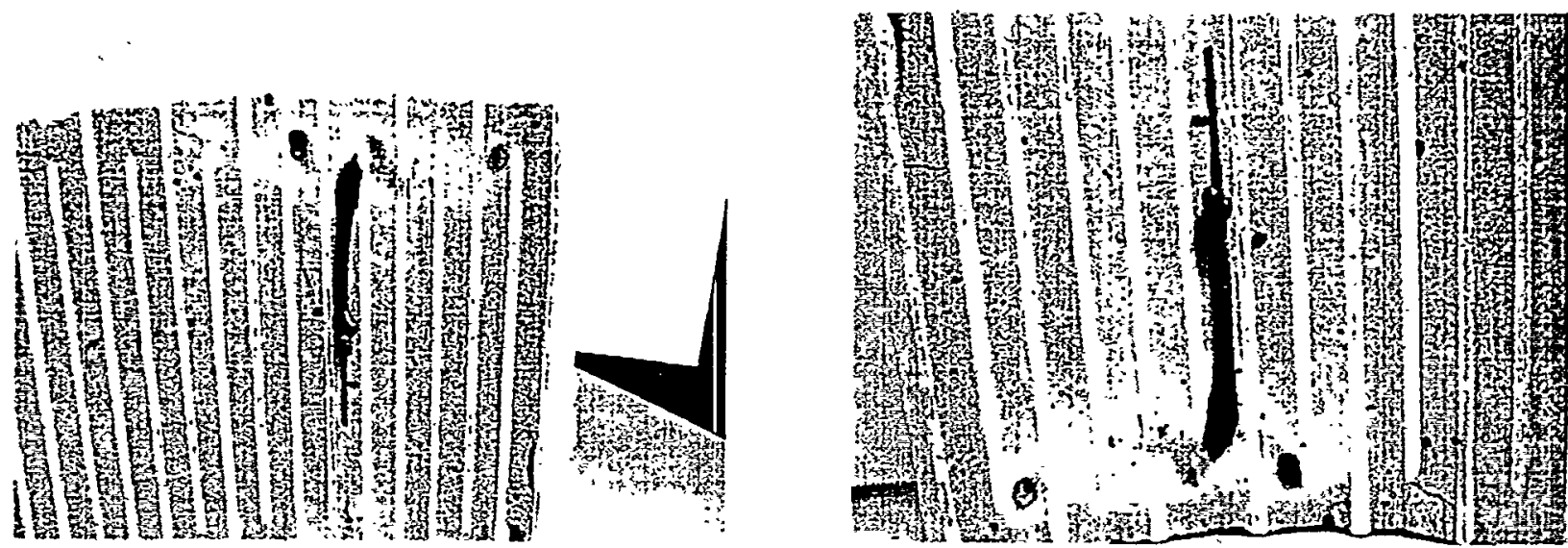
TEMPERATURE PROFILES FOR GLASS FLOW EXPERIMENTS PERFORMED ON THIRTEEN DIFFERENT DATES 


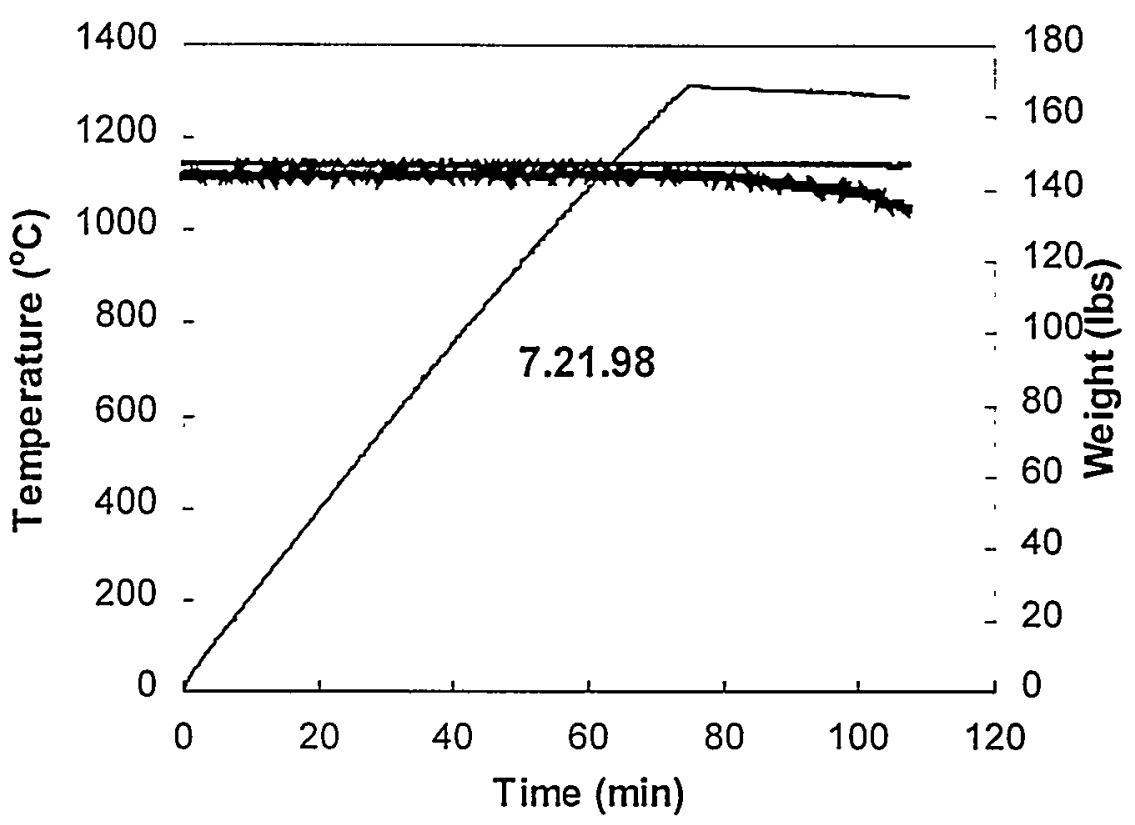

_ Glass Temperature —Spout Temperature —Weight

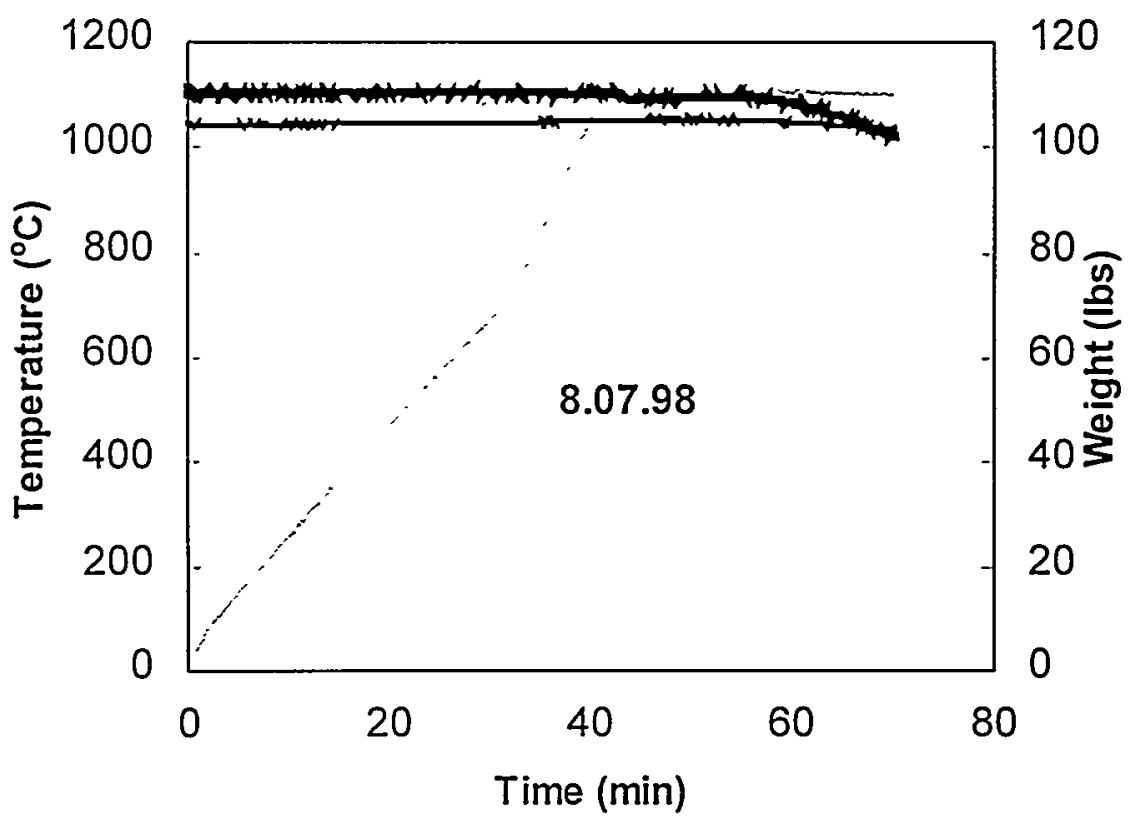

- Glass Temperature _-Spout Temperature —Weight 


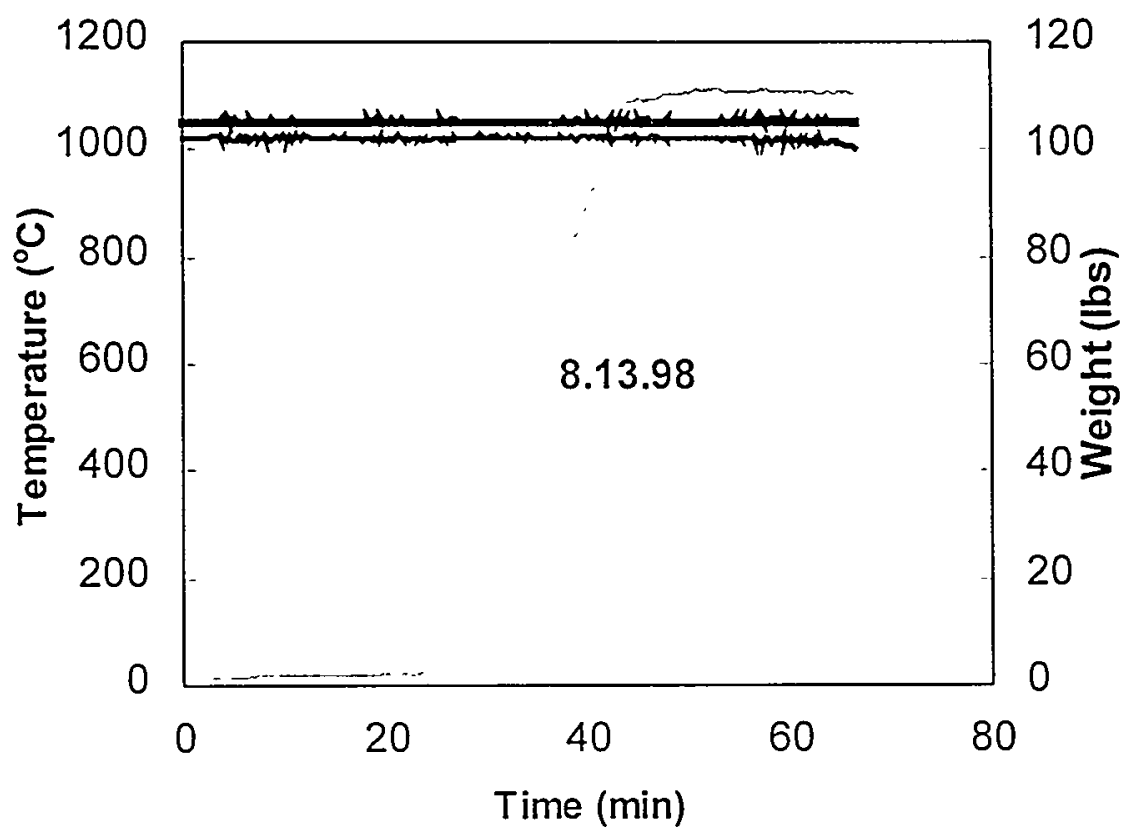

_Glass Temperature __ Spout Temperature ___ Weight

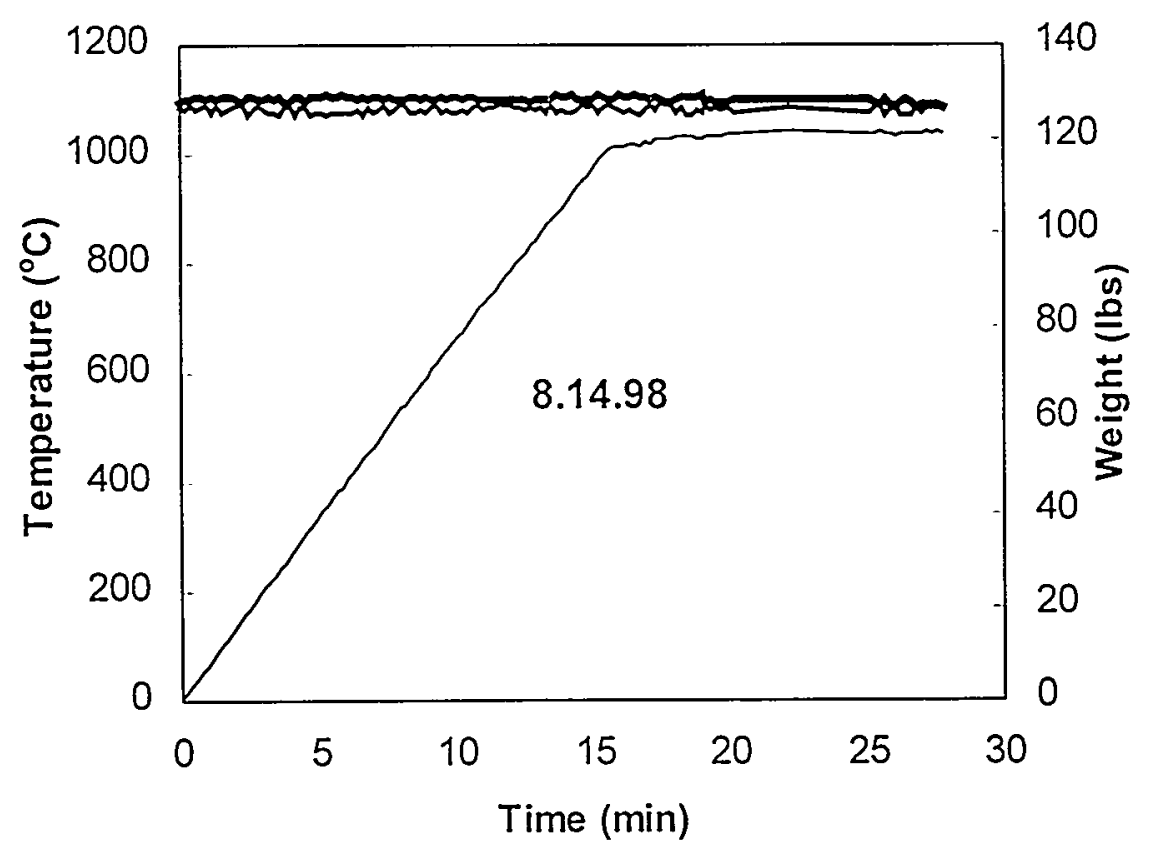

_ Glass Temperature __ Spout Temperature _- Weight 


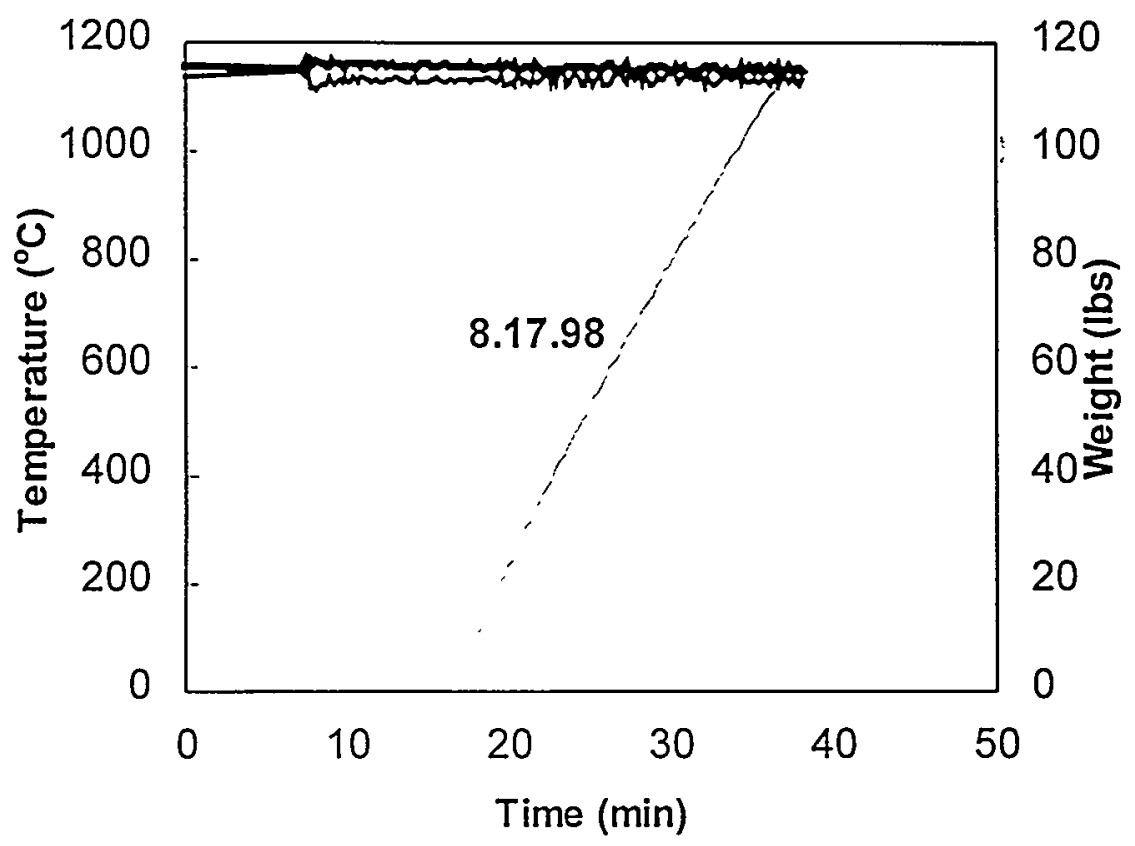

_ Glass Temperature __ Spout Temperature __Weight

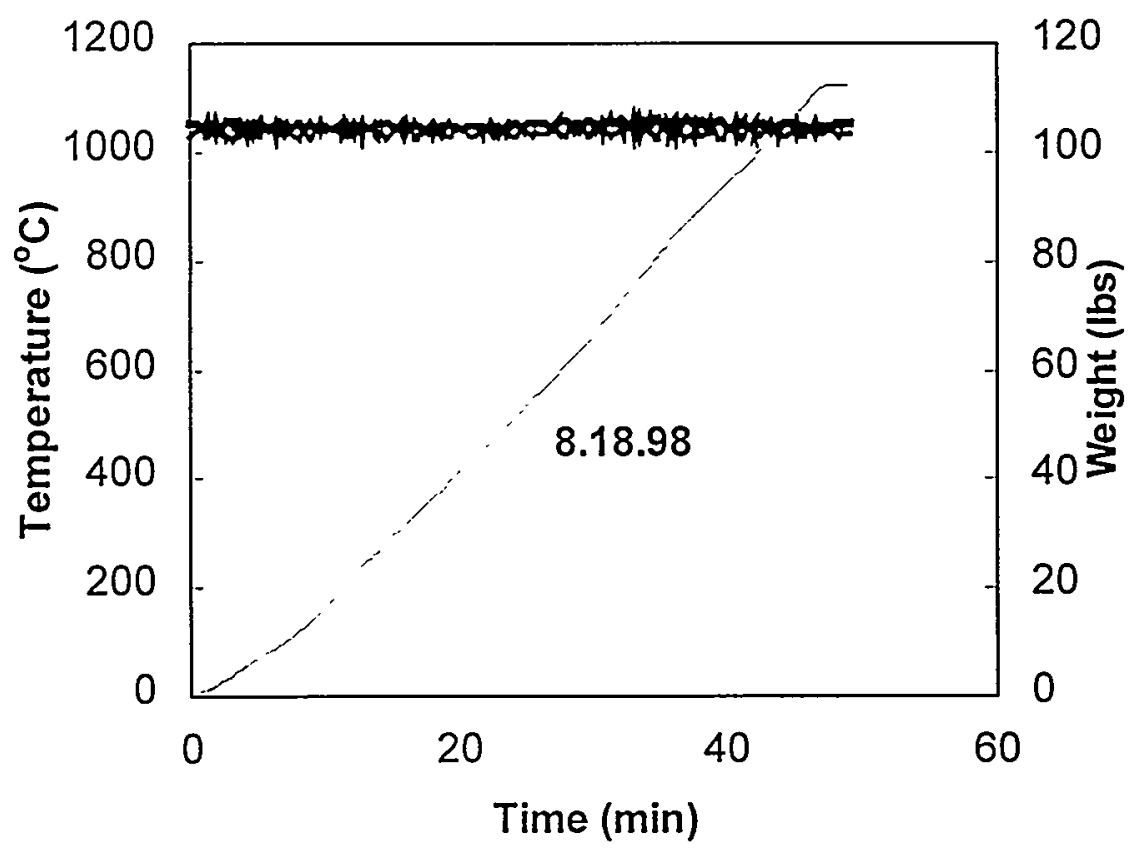

_ Glass Temperature __ Spout Temperature _ Weight 

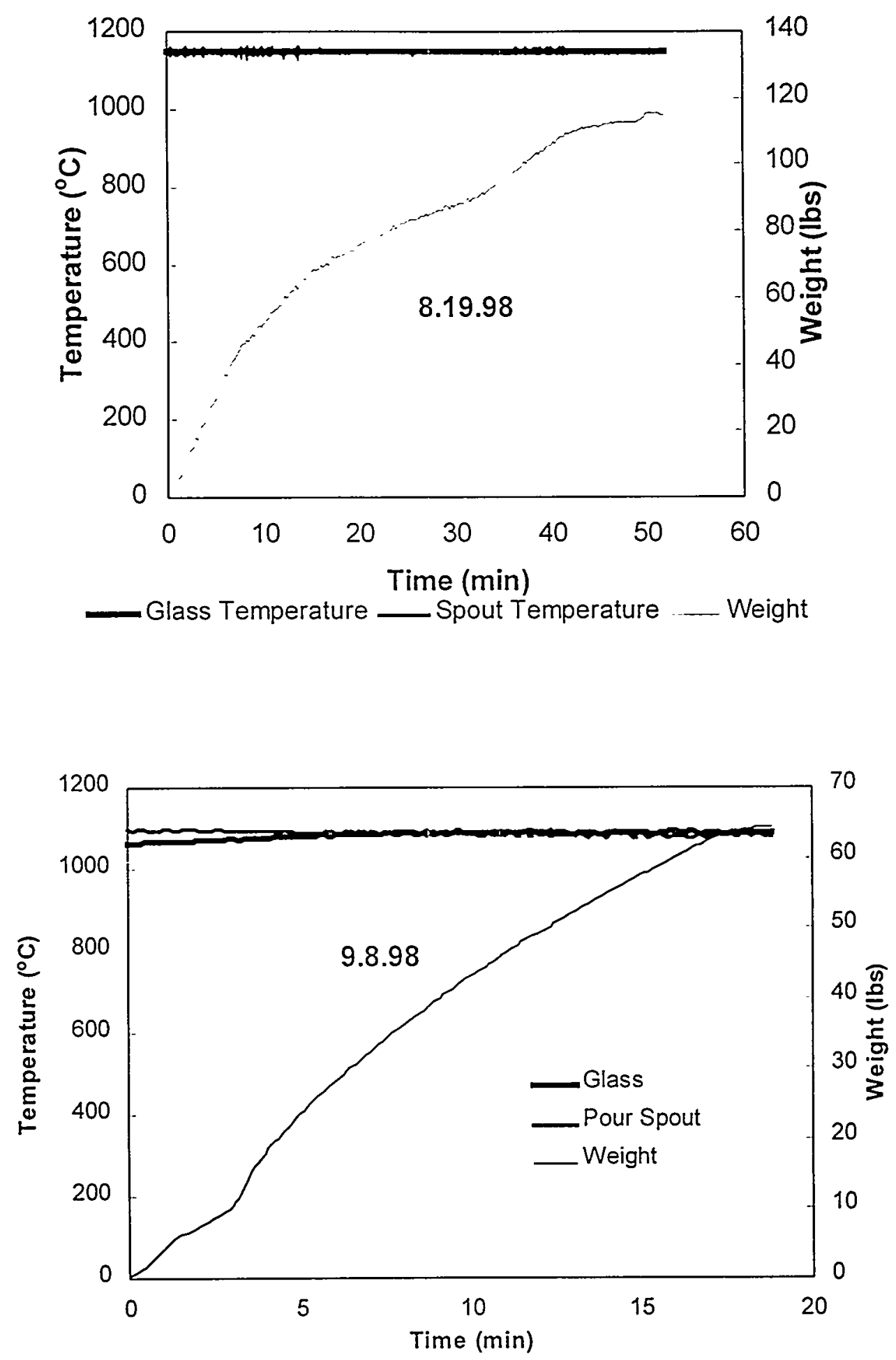

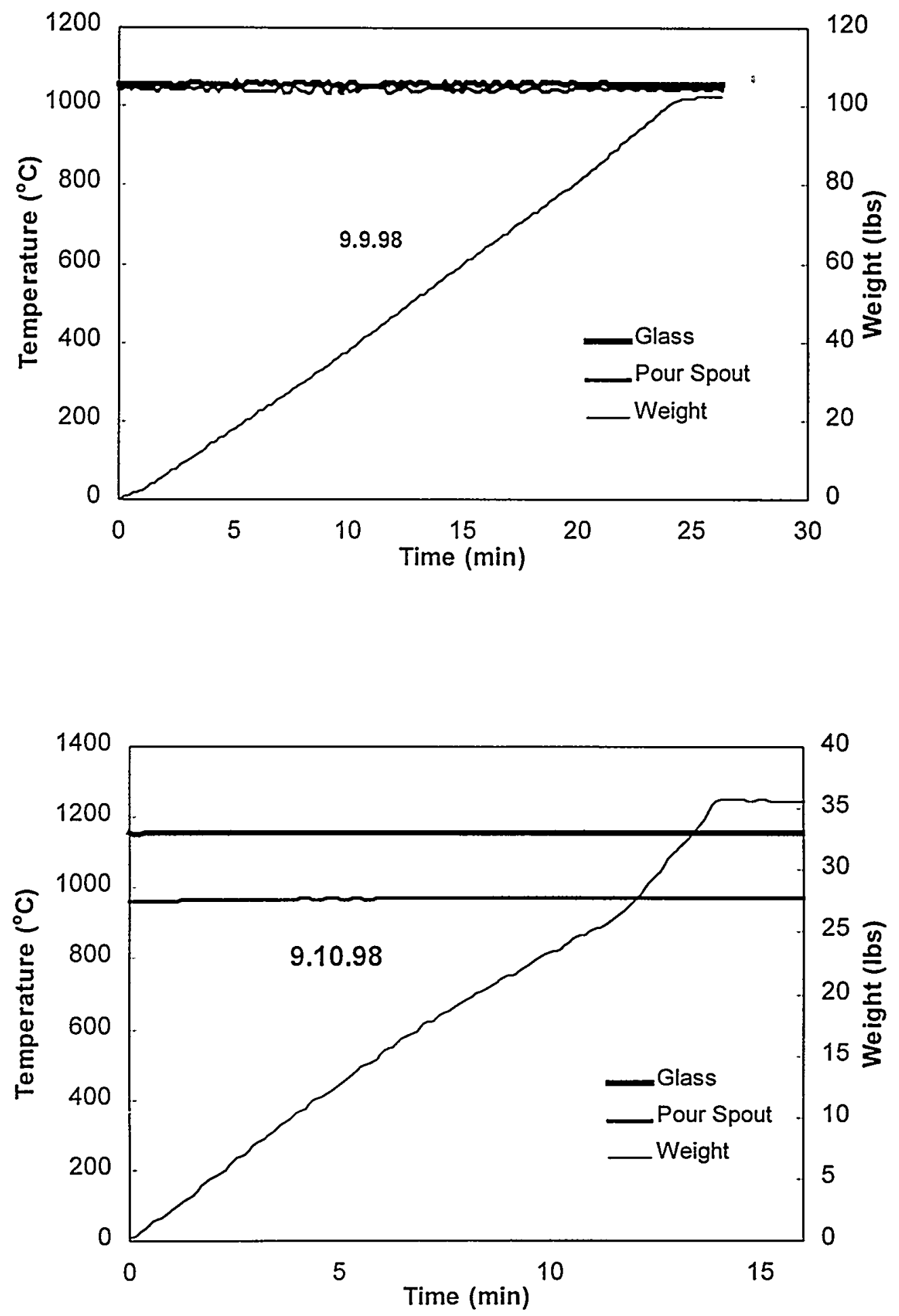

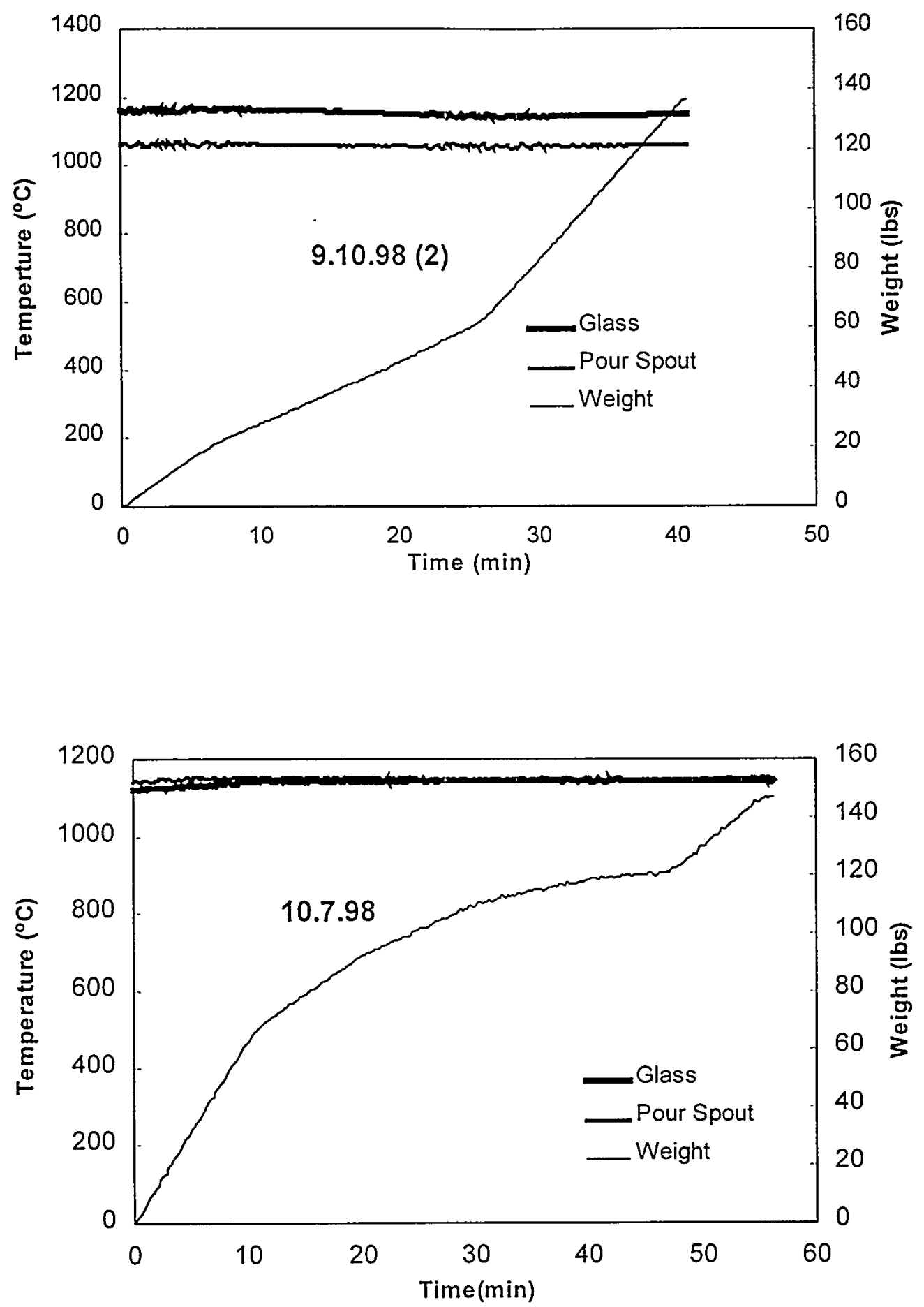


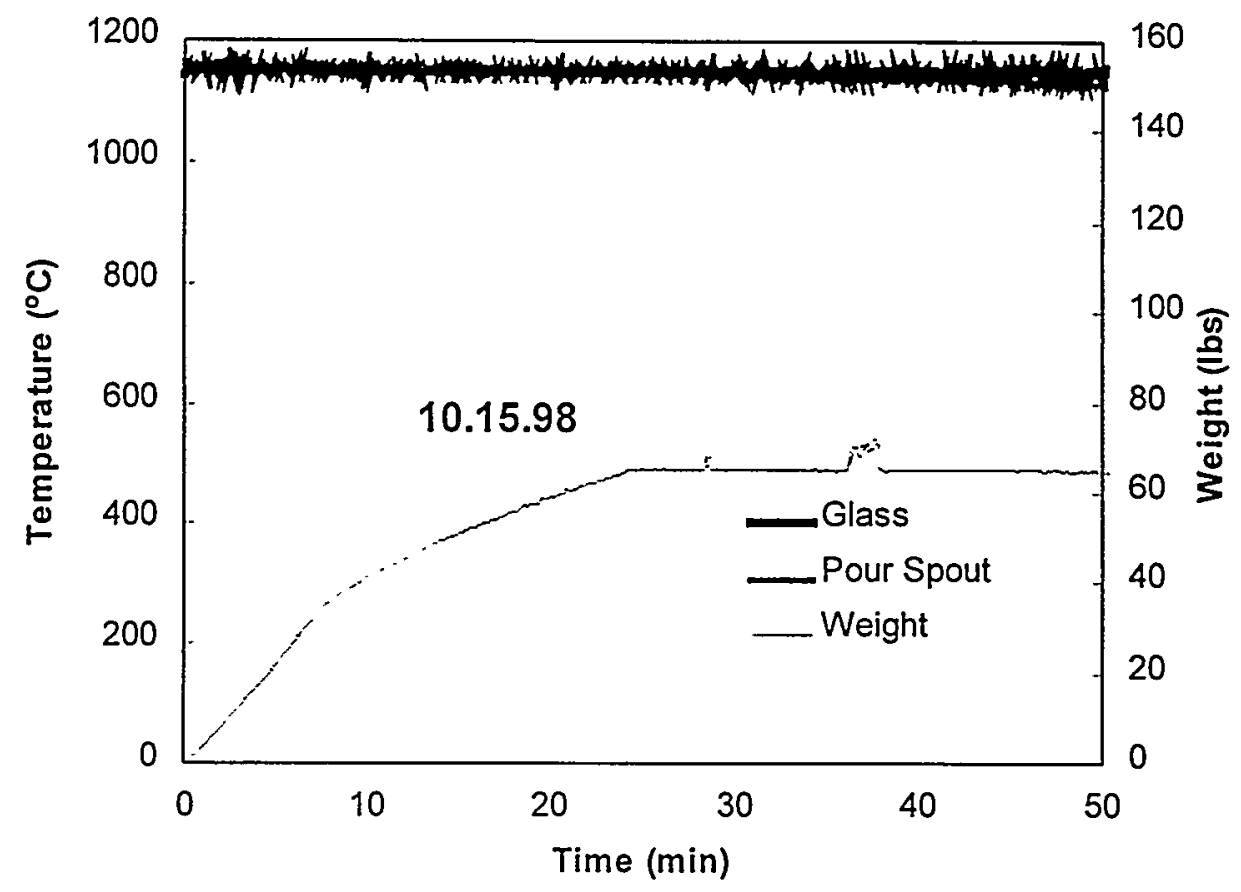

